\title{
30. NEOGENE PLANKTONIC FORAMINIFERA FROM THE CENTRAL NORTH PACIFIC, LEG 32, DEEP SEA DRILLING PROJECT
}

\author{
Edith Vincent, Scripps Institution of Oceanography, La Jolla, California
}

\begin{abstract}
Three sites (Sites 305, 310, and 313) drilled during DSDP Leg 32 in the central North Pacific recovered Neogene calcareous sediments. These sites, now located between 2900 and 3500 meters water depth, lay below the lysocline throughout the time of deposition. Site 313, within a basin in the Mid-Pacific Mountains, is at a locale subject to slumping and has little biostratigraphic value. Sites 305 and 310 , located on Shatsky Rise and Hess Rise, respectively, provide a valuable record of late Neogene planktonic foraminiferal and paleooceanographic events. The occurrence of calcareous and siliceous microfossils in these two sections permits the direct comparison and correlation of zonation schemes based on the two microfossil types. The positions of the Plio-Pleistocene and MioPliocene boundaries, placed at the oldest occurrence of Globorotalia truncatulinoides and $G$. tumida, respectively, are in good agreement with the boundaries based on other microfossil zonations.

Robust, temperate-water forms of Globorotalia that make up the $G$. conoidea to $G$. inflata bioseries are consistent elements of the Pliocene and Pleistocene assemblages. The lowest appearances of $G$. conoidea at the Miocene/Pliocene boundary and Neogloboquadrina pachyderma in the uppermost Miocene result from improved preservation of calcareous material above those levels. The disappearance of Globoquadrina dehiscens in this area is associated with a late Miocene cooling. This species disappears earlier at the higher latitude Site 310 than at Site 305. Globorotalia puncticulata and G. crassaformis first appear at about 4.0 to 4.2 m.y. B.P. simultaneously with the radiolarian species Lamprocyclas heteroporos. This level, which approximates the first occurrence of Sphaeroidinella dehiscens in temperate latitudes of the North Pacific and has been taken as the Mio-Pliocene boundary in marine sections of the northeastern Pacific margin, is approximately $1 \mathrm{~m} . \mathrm{y}$. younger than the type MioPliocene boundary in Italy. The disappearance of keeled forms of the $G$. conoidea-G. inflata group (represented by $G$. conoidea s.l.) at approximately $2.7-2.8$ m.y. B.P. is followed very shortly by the first appearance of $G$. inflata, which apparently migrated into the North Pacific slightly later than elsewhere.

Late Neogene sediments younger than approximately 6.3 m.y. were deposited with an average rate of accumulation of 7.6 to 10.8 $\mathrm{m} / \mathrm{m} . \mathrm{y}$., with an increased rate in late Pliocene and a 1-m.y. interval of nondeposition in the late early Pliocene. Neogene sediments older than 6.3 m.y. accumulated at a much lower average rate, resulting in a very condensed series lying unconformably on sediments of Oligocene age.

Coiling changes in populations of $N$. pachyderma reflect surfacetemperature variations. The substantial late Miocene cooling observed in marine sections throughout the margins of the North Pacific resulted in the southward shift of the $10^{\circ} \mathrm{C}$ surface isotherm over Hess Rise. A sharp decrease in calcium-carbonate dissolution, reflected in both sequences by a change in dissolution facies, occurs near the Mio-Pliocene boundary and is probably correlated with the abrupt drop of the CCD at that time in equatorial regions of the Pacific.
\end{abstract}

\section{INTRODUCTION}

Calcareous Neogene sections were recovered at three of the drilling sites (Table 1) during DSDP Leg 32 in the North Pacific. Sites 305 and 310 are located on Shatsky and Hess rises, respectively. These rises are broad, irregularly shaped plateaus, broken into blocks by normal faulting and elevated above the surrounding abyssal sea floor. Site 313 lies within a basin among the seamounts of the northeastern Mid-Pacific Mountains. 
TABLE 1

Site Location

\begin{tabular}{lcccl}
\hline Site & Latitude & Longitude & $\begin{array}{c}\text { Water } \\
\text { Depth } \\
(\mathrm{m})\end{array}$ & Geographical Area \\
\hline 305 & $32^{\circ} 00.13^{\prime} \mathrm{N}$ & $157^{\circ} 51.00^{\prime} \mathrm{E}$ & 2903 & Shatsky Rise \\
310 & $36^{\circ} 52.11^{\prime} \mathrm{N}$ & $176^{\circ} 54.09^{\prime} \mathrm{E}$ & 3516 & Hess Rise \\
313 & $20^{\circ} 10.52^{\prime} \mathrm{N}$ & $170^{\circ} 57.15^{\prime} \mathrm{W}$ & 3484 & Mid-Pacific Mountains \\
\hline
\end{tabular}

Sites 305 and 313 are located beneath the sterile subtropic gyre, whereas Site 310 lies beneath the Kuroshio Extension Current in the vicinity of the mixing boundary of Kuroshio Extension and Oyashio currents (Figure 1). All three sites are above the calcium compensation depth (CCD) which, in this area of the North Pacific, lies between 4000 and 4500 meters (Berger and Winterer, 1974). The sites are, however, below the foraminiferal lysocline (the surface that separates wellpreserved from noticeably dissolved foraminiferal assemblages, Berger, 1968, 1970) as shown by the advanced degree of dissolution of planktonic foraminiferal tests. At all three sites, foraminiferal fragmentation is extensive, benthonic species (which are more resistant to dissolution than planktonic species) make up a significant proportion of the fauna, and assemblages are dominated by those planktonic species resistant to dissolution (Table 2). These conditions appear to have prevailed throughout the Neogene.

The value of these sites for biostratigraphic and paleooceanographic investigations may be decreased because selective dissolution of planktonic foraminiferal species may bias the interpretation of an assemblage (Berger, 1968, 1970). Valuable information, however, was obtained from the residual assemblages, especially at Sites 305 and 310, which were continuously cored with good recovery. The sections at these sites are among the very few available deep-sea calcareous sections from the Pacific from an area between the subtropical and temperate regions. Siliceous and calcareous fossils commonly occur throughout the 52 and 80 meter sections of Shatsky and Hess rises, which makes possible a comparison between zonations of various fossil groups. The uppermost Miocene to Pleistocene sequences, which accumulated with an average rate of about $8 \mathrm{~m} / \mathrm{m} . \mathrm{y}$. on Shatsky Rise and $11 \mathrm{~m} / \mathrm{m} . \mathrm{y}$. on Hess Rise, are of particular interest. The lower upper, middle, and lower Miocene sections are extremely condensed, with a number of hiatuses, and are of lesser value. Middle Miocene sediments lie unconformably upon those of early Oligocene age at Site 310 and lower Miocene sediments rest above those of late Oligocene age at Site 305 .

Site 313, which was cored discontinuously, is of little biostratigraphic value. Mixed redeposited sediments were commonly recovered because the site is in a region of rugged relief, surrounded by topographic highs, and therefore is a locale of slumping.

\section{METHODS}

Samples of approximately $10 \mathrm{cc}$ were washed through a $63 \mu \mathrm{m}$ mesh sieve. The sampling interval used was about 1.5 meters (each $9-\mathrm{m}$ core was routinely cut into six sections; one sample from each section and one from each core catcher were examined). Dried samples were weighed before and after washing to obtain the percentage of sand-size components.

Qualitative estimates of the abundance of the various sand-size components, as well as preservation of foraminiferal faunas are given in Tables 3-5. After this preliminary examination, the samples were divided into two sieve fractions of $\pm 149 \mu \mathrm{m}$. The finer fractions were found to contain abundant fragments, but very few whole tests of planktonic foraminifera. Most planktonic species from the coarser fraction were examined. Abundances of species were visually estimated and are indicated in Tables 6-8. The ranges of selected key species from Sites 305 and 310 are plotted on Figures 2 and 3 against the stratigraphic section and various planktonic zonations.

Detailed quantitative faunal analyses were undertaken only on the highest sample at each site. The relative frequency of each species was obtained by counting about 300 specimens in each sample (Table 2).

\section{PLANKTONIC ZONATIONS}

Foraminiferal zonations of the late Cenozoic include those developed by Bolli $(1957,1966,1970)$, Banner and Blow (1965), Blow (1969), and Jenkins and Orr (1972) for the tropical areas; by Jenkins $(1966,1967 \mathrm{a}, 1971)$ and Kennett (1973) for the temperate regions of New Zealand and southwestern Pacific; and by Kennett (1973) for that part of the southwestern Pacific intermediate between temperate and subtropical areas. The differences in stratigraphic ranges of important taxa under different climatic regimes make the correlation of zonal schemes of various areas difficult.

Planktonic faunas encountered at Sites 305 and 310 are dominated by temperate species but also include subtropical elements. The abbreviated "letter-number" system of Blow (1969), found convenient because of its brevity, is employed here. However, in a number of cases zonal boundaries could not be recognized because of the lack or rarity of the nominate zonal taxa. In these cases the boundaries were tentatively drawn on the basis of the associated faunal assemblage. The simultaneous occurrence at Sites 305 and 310 of calcareous and siliceous microfossils is of special interest. These sequences permit direct comparison and correlation of zonation schemes based on the two microfossil types. One of the most remarkable advances in stratigraphy in recent years has been made by the interrelating of planktonic biostratigraphy with the paleomagnetic reversal scale (Hays et al., 1969; Hays, 1970; Gartner, 1973; Theyer and Hammond, 1974; Saito et al., in 

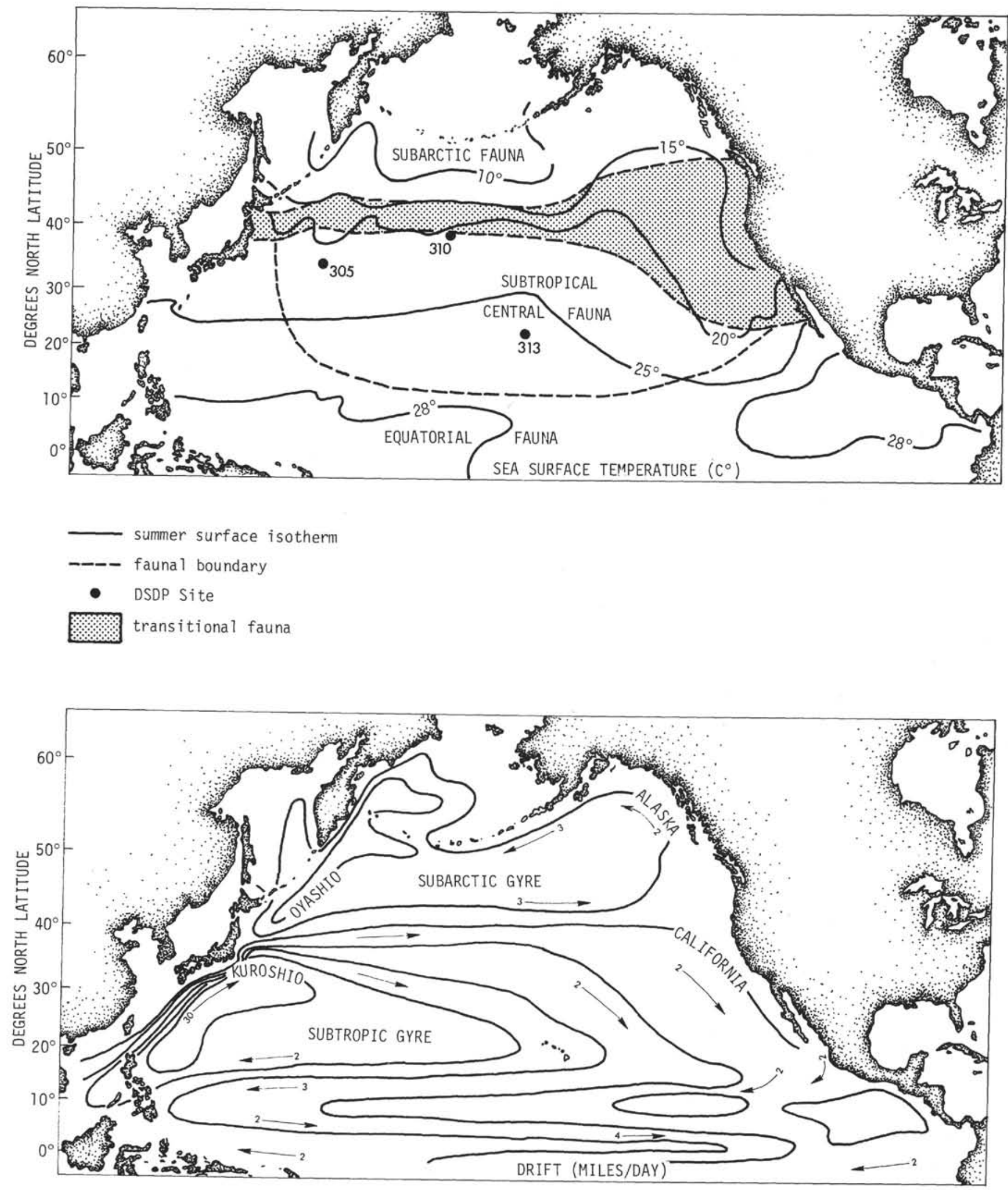

Figure 1. Site location and distribution of surface temperatures, living faunal assemblages, and major currents in the North Pacific Ocean. Adapted from Bradshaw (1959) and Tully (1965). 
TABLE 2

Faunal Composition in the Highest Samples Recovered at Sites 305, 310, and 313

\begin{tabular}{|c|c|c|c|}
\hline & \multicolumn{3}{|c|}{ Sample (Interval in $\mathrm{cm}$ ) } \\
\hline & $305-1-2,100-102$ & $310-1-1,5-7$ & $313-1-1,100-102$ \\
\hline Globigerinoides ruber & 3.6 & 1.5 & 6.7 \\
\hline Globigerinella siphonifera & 0.5 & & \\
\hline Globigerinoides conglobatus & & & 3.2 \\
\hline Turborotalita quinqueloba & & 2.2 & \\
\hline Globigerina bulloides & 8.6 & 13.4 & \\
\hline Globigerinita glutinata & 5.0 & 5.2 & \\
\hline Globigerina falconensis & 4.1 & & \\
\hline Orbulina universa & 6.3 & 2.2 & 5.8 \\
\hline Globorotalia scitula & 1.4 & & \\
\hline Globigerina digitata & & & 1.3 \\
\hline Globorotalia hirsuta & 1.4 & & \\
\hline Globorotalia truncatulinoides & 0.5 & 4.5 & \\
\hline Globorotalia inflata & 52.0 & 20.9 & \\
\hline Globorotalia crassaformis & & & 2.9 \\
\hline Globorotalia menardii & & & 0.6 \\
\hline Neogloboquadrina pachyderma & 13.6 & 47.0 & \\
\hline Sphaeroidinella dehiscens & & & 24.0 \\
\hline Globorotalia tumida & & & 55.6 \\
\hline Benthonic foraminiferal species & 19.0 & 9.0 & 52.4 \\
\hline Radiolarians & 3.9 & 41.5 & \\
\hline Fragments/whole-test planktonic forams & 1.67 & 1.08 & 20.58 \\
\hline
\end{tabular}

Note: Relative frequencies of planktonic species expressed as percentages of the total planktonic foraminiferal population larger than $149 \mu \mathrm{m}$. Planktonic species ranked in order of decreasing susceptibility to solution (Parker and Berger, 1971). Percentages of benthonic species versus total foraminiferal population. Percentages of radiolarian species versus total radiolarians + planktonic foraminifera. Ratio of planktonic foraminiferal fragments to whole-test planktonic foraminifera.

press). A number of planktonic datum planes paleomagnetically-radiometrically dated have proved to be reliable in both high and low latitudes, especially among radiolarians. Several of these levels were recognized in the Shatsky and Hess rise sections. The correlation and time relationships of the various zonal schemes applied to these sections by Foreman (this volume), Bukry (this volume), and in this paper, are shown in Figure 4. Absolute ages were assigned to a number of horizons in the Shatsky and Hess rise sections, and sedimentation rates as well as the age of planktonic foraminiferal events were estimated (Figure 5).

\section{EPOCH BOUNDARIES}

\section{Pliocene/Pleistocene Boundary}

A number of paleontological events closely associated with the Olduvai normal paleomagnetic event (Gilsa event of Cox, 1969), approximately 1.7-1.8 m.y. B.P., have been used as criteria for defining the Plio-Pleistocene boundary. These events include the extinction of the nannofossil genus Discoaster (in the form of $D$. brouweri) and the evolutionary appearances of the foraminiferal species Globorotalia truncatulinoides and the radiolarian Eucyrtidium matuyamai (Ericson et al., 1963; Banner and Blow, 1965; Berggren et al., 1967; Glass et al., 1967; Hays et al., 1969; Hays, 1970; Hays and Berggren, 1971).

At both Sites 305 and 310 the evolutionary development of $G$. truncatulinoides from its ancestor $G$. tosaensis is not well represented because of the scarcity of the latter species. G. truncatulinoides, however, first occurs at or near the Plio-Pleistocene boundary as defined by other fossil groups. The base of the range of $G$. truncatulinoides coincides with the base of the Eucyrtidium matuyamai Zone at both Sites 305 and 310. This level approximates the Plio-Pleistocene boundary based on nannofossil data at Site 310, but at Site 305 the nannofossil zonation indicates a slightly lower position for the boundary.

\section{Miocene/Pliocene Boundary}

The type Mio-Pliocene boundary occurs between the late Miocene Messinian and the early Pliocene Tabianian (equals Zanclean of Sicily) stages of Italy. Evidence for the age of this type boundary has been summarized by Berggren (1973) and Berggren and Van Couvering (1974). These authors placed the Mio-Pliocene boundary at approximately $5 \mathrm{~m}$.y. in the lowermost reversed interval of the Gilbert paleomagnetic epoch on the basis of biostratigraphic correlation with paleomagnetically and radiometrically dated cores outside the Mediterranean area. This is the level of appearance of the nannofossil Ceratolithus acutus and the foraminifer Globorotalia tumida (Gartner, 1973; Saito et al., in press).

Good agreement was found for the definition of the Mio-Pliocene boundary based on foraminiferal and nannofossil zonations at both Sites 305 and 310 . The evolutionary development of $G$. tumida from its ancestor G. plesiotumida is not well represented here because of the scarcity of the latter species. However, when $G$. tumida first appears, at the base of the Ceratolithus acutus Zone, it shows as a primitive form. 
TABLE 3

Sediment Coarse Fraction $(>63 \mu)$ Components and Foraminiferal Preservation at Site 305

\begin{tabular}{|c|c|c|c|c|c|c|c|c|c|c|c|c|c|c|c|c|}
\hline \multirow[b]{2}{*}{$\begin{array}{c}\text { Sample } \\
\text { (Interval in } \mathrm{cm} \text { ) }\end{array}$} & \multirow[b]{2}{*}{$\begin{array}{l}\text { Depth in } \\
\text { Hole (m) }\end{array}$} & \multirow[b]{2}{*}{ 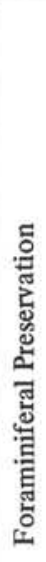 } & \multicolumn{14}{|c|}{ Sediment Coarse Fraction Components } \\
\hline & & & 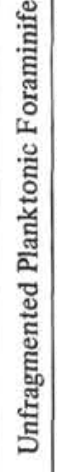 & 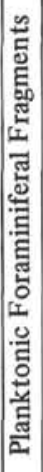 & 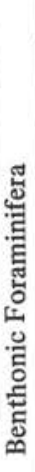 & 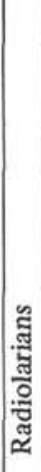 & 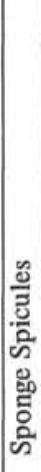 & 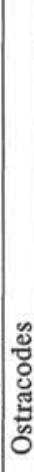 & 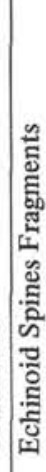 & 迎 & 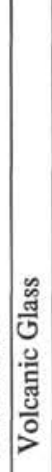 & 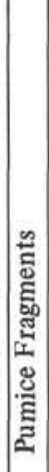 & 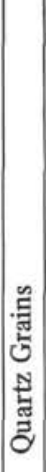 & 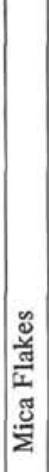 & 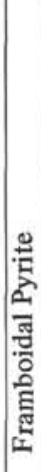 & 总 \\
\hline $1-2,100-102$ & $1.50-1.52$ & $\mathrm{P}$ & A & A & $\mathrm{C}$ & $\mathrm{R}$ & $\mathrm{R}$ & & $\mathbf{P}$ & & C & & & & & \\
\hline $1-3,40-42$ & $2.40-2.42$ & $\mathrm{P}$ & $\mathrm{A}$ & A & $\mathrm{C}$ & $\mathrm{R}$ & $\mathrm{R}$ & & & & & & & & & \\
\hline $1-3,118-120$ & $3.18-3.20$ & $\mathrm{P}$ & $\mathrm{A}$ & $\mathrm{C}$ & C & $\mathrm{R}$ & $\mathrm{R}$ & & & & $\mathrm{R}$ & & & & & \\
\hline $1-4,58-60$ & $4.08-4.10$ & $\mathrm{P}$ & $\mathrm{A}$ & $\mathrm{A}$ & $\mathrm{C}$ & $\mathrm{R}$ & & & $\mathrm{P}$ & & & & & & & \\
\hline $1-5,30-32$ & $5.30-5.32$ & $\mathrm{P}$ & $\mathrm{A}$ & A & $\mathrm{C}$ & $\mathrm{R}$ & $\mathrm{R}$ & & & & & & & & & \\
\hline $1-6,70-72$ & $7.20-7.22$ & $\mathrm{P}$ & $\mathrm{A}$ & A & R & $\mathrm{R}$ & $\mathrm{R}$ & & & & & & & & & \\
\hline $1, \mathrm{CC}$ & 8.00 & $\mathrm{P}$ & $\mathrm{A}$ & $\mathrm{A}$ & $\mathrm{R}$ & $\mathrm{R}$ & $\mathrm{R}$ & & & & & & & & & \\
\hline $2-1,90-92$ & $8.90-8.92$ & $\mathrm{P}$ & $\mathrm{A}$ & $\mathrm{A}$ & $\mathrm{R}$ & $\mathrm{R}$ & $\mathrm{R}$ & & & & & & & & & \\
\hline $2-2,125-127$ & $10.75-10.77$ & $P$ & $\mathrm{~A}$ & $\mathrm{~A}$ & $\mathrm{R}$ & $\mathrm{R}$ & $\mathrm{R}$ & & $\mathrm{P}$ & & $\mathrm{R}$ & & & & & \\
\hline $2-3,136-138$ & $12.36-12.38$ & $\mathrm{P}$ & $\mathrm{A}$ & $\mathrm{A}$ & $\mathrm{R}$ & $\mathrm{R}$ & $\mathrm{R}$ & & & & & & & & & \\
\hline $2, \mathrm{CC}$ & 12.50 & $\mathbf{P}$ & $\mathrm{A}$ & A & $\mathrm{R}$ & $\mathrm{R}$ & $\mathrm{R}$ & & $\mathbf{P}$ & & $\mathrm{R}$ & & & & & \\
\hline $3-1,108-110$ & $18.08-18.10$ & $\mathrm{P}$ & $\mathrm{A}$ & $\mathrm{A}$ & $\mathrm{R}$ & $\mathrm{R}$ & R & $\mathbf{P}$ & & & & & & & & \\
\hline $3-2,118-120$ & $19.68-19.70$ & $\mathrm{P}$ & $\mathrm{A}$ & $\mathrm{A}$ & $\mathrm{R}$ & $\mathrm{R}$ & $\mathrm{R}$ & & & & $\mathrm{R}$ & & & & & \\
\hline $3-3,135-137$ & $21.35-21.37$ & $\mathrm{P}$ & $\mathrm{C}$ & A & $\mathrm{C}$ & $\mathrm{R}$ & $\mathrm{R}$ & & & & $\mathrm{R}$ & & & & & \\
\hline $3, \mathrm{CC}$ & 21.50 & $\mathrm{P}$ & $\mathrm{C}$ & A & $\mathrm{C}$ & $\mathrm{R}$ & $\mathrm{R}$ & $\mathbf{P}$ & & & $\mathrm{R}$ & & & & & \\
\hline $4-1,136-138$ & $27.86-27.88$ & $\mathrm{P}$ & $\mathrm{C}$ & A & $\mathrm{C}$ & $\mathrm{R}$ & $\mathrm{R}$ & & $\mathbf{P}$ & & $\mathrm{R}$ & & & & & \\
\hline $4-2,135-137$ & $29.35-29.37$ & $\mathbf{P}$ & $\mathrm{C}$ & A & C & R & R & & $\mathbf{P}$ & & $\mathbf{R}$ & & & & & \\
\hline $4-3,122-125$ & $30.72-30.75$ & $\mathrm{P}$ & $\mathrm{C}$ & A & $\mathrm{C}$ & $\mathrm{R}$ & $\mathrm{R}$ & & & & $\mathrm{R}$ & & & & & \\
\hline $4, \mathrm{CC}$ & 31.00 & $\mathrm{P}$ & $\mathrm{C}$ & $\mathrm{A}$ & C & $\mathrm{R}$ & $\mathrm{R}$ & & & & $\mathrm{R}$ & & & & & \\
\hline $5-1,124-127$ & $36.74-36.77$ & $\mathrm{P}$ & $\mathrm{C}$ & $A$ & C & $\mathrm{R}$ & $\mathrm{R}$ & & & & & & & & & \\
\hline $5-2,122-125$ & $38.22-38.25$ & $\mathrm{P}$ & $\mathrm{R}$ & A & C & $\mathrm{R}$ & $\mathrm{R}$ & & & & & & & & & \\
\hline $5-3,122-125$ & $39.72-39.75$ & $\mathrm{P}$ & $\mathrm{C}$ & A & $\mathrm{C}$ & $\mathrm{R}$ & $\mathrm{R}$ & & $\mathrm{C}$ & & & & & & & \\
\hline $5-4,122-125$ & $41.22-41.25$ & $\mathrm{P}$ & $\mathrm{R}$ & $\mathrm{C}$ & $\mathrm{A}$ & & $\mathrm{R}$ & & $\mathrm{C}$ & & & & & & & \\
\hline $5-5,122-125$ & $42.72-42.75$ & $P$ & $\mathrm{C}$ & C & $\mathrm{C}$ & & $\mathrm{R}$ & $\mathrm{P}$ & $\mathrm{R}$ & & $\mathrm{R}$ & & & & & \\
\hline $5, \mathrm{CC}$ & 43.00 & $\mathrm{P}$ & $\mathrm{C}$ & C & $\mathrm{C}$ & & $\mathrm{R}$ & $\mathrm{P}$ & $\mathrm{R}$ & $\mathbf{P}$ & $\mathrm{R}$ & & & & $\mathrm{R}$ & \\
\hline $6-1,129-130$ & $46.29-46.30$ & $\mathrm{P}$ & $\mathrm{C}$ & $A$ & C & & & & $\mathrm{R}$ & $\mathrm{P}$ & C & & & $\mathrm{R}$ & & \\
\hline $6-2,133-135$ & $47.83-47.85$ & $\mathrm{P}$ & $\mathrm{R}$ & $\mathrm{A}$ & $\mathrm{C}$ & & $\mathrm{R}$ & & $\mathrm{R}$ & $\mathrm{P}$ & $\mathrm{R}$ & & $\mathrm{R}$ & $\mathrm{R}$ & $\mathrm{R}$ & $\mathrm{R}$ \\
\hline $6-3,137-139$ & $49.37-49.39$ & $P$ & $\mathrm{C}$ & $\mathrm{A}$ & $\mathrm{C}$ & & $\mathrm{R}$ & & $\mathrm{R}$ & $\mathrm{P}$ & & & & & & \\
\hline $6-4,136-139$ & $50.86-50.89$ & $\mathrm{P}$ & $\mathrm{C}$ & $\mathrm{A}$ & $\mathrm{C}$ & & & $\mathrm{P}$ & $\mathrm{R}$ & $\mathrm{P}$ & $\mathrm{R}$ & & & & & $\mathrm{R}$ \\
\hline $6-5,30-32$ & $51.30-51.32$ & $\mathbf{P}$ & $\mathrm{C}$ & A & $\mathrm{C}$ & & & & $\mathrm{R}$ & & R & & & & & $\mathrm{C}$ \\
\hline $6-5,110-112$ & $53.60-53.62$ & $P$ & $\mathrm{C}$ & C & C & & & $\mathbf{P}$ & & $\mathrm{P}$ & $R$ & & & & & C \\
\hline
\end{tabular}

Note: Components abundance: $\mathrm{A}$, abundant; $\mathrm{C}$, common; $\mathrm{R}$, rare; $\mathrm{P}$, present. Preservation: $\mathrm{G}$, good; $\mathrm{M}$, moderate; $\mathrm{P}$, poor.

The Mio-Pliocene boundary, based on calcareous plankton, correlates at both sites with the base of the Sphaeropyle langii radiolarian Zone of Foreman (this volume) defined by the first morphological appearance of $S$. langii. The size and regularity of the pores of the second shell are used by Foreman (this volume) to distinguish $S$. langii from $S$. robusta. The use of this criteria gives a somewhat longer morphological range for $S$. langii than indicated by Kling (1973).

\section{PLANKTONIC FORAMINIFERAL EVENTS}

Members of the Globorotalia miozea-conoideaconomiozea-sphericomiozea-puncticulata-inflata evolutionary series are a planktonic group of biostratigraphic importance in temperate areas. Kennett (1966, 1967, 1973) and Kennett and Watkins (1974) described from sediments from New Zealand and the southwest Pacific the evolution of Globorotalia conoidea (referred 
TABLE 4

Sediment Coarse Fraction $(>63 \mu)$ Components and

Foraminiferal Preservation at Site $\mathbf{3 1 0}$

\begin{tabular}{|c|c|c|c|c|c|c|c|c|c|c|c|c|c|c|c|c|}
\hline \multirow[b]{2}{*}{$\begin{array}{c}\text { Sample } \\
\text { (Interval in } \mathrm{cm} \text { ) }\end{array}$} & \multirow[b]{2}{*}{$\begin{array}{l}\text { Depth in } \\
\text { Hole (m) }\end{array}$} & \multirow[b]{2}{*}{ 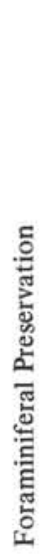 } & \multicolumn{14}{|c|}{ Sediment Coarse Fraction Components } \\
\hline & & & 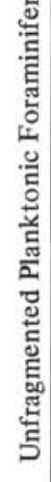 & 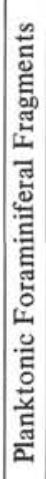 & 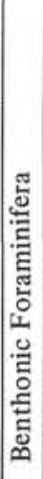 & 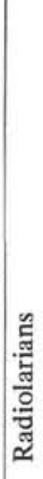 & 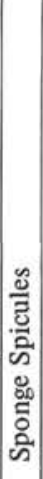 & 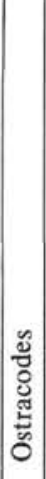 & 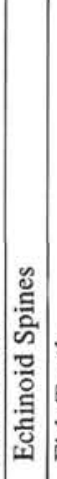 & 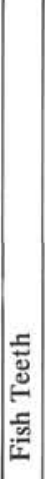 & 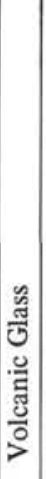 & 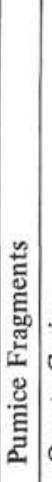 & 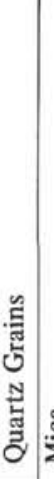 & 荧 & 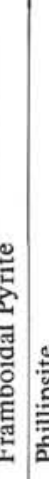 & \\
\hline $1-1,5-7$ & $0.05-0.07$ & $\mathrm{P}$ & $\mathrm{C}$ & C & C & C & & & & & & & & & & \\
\hline $1-2,33-35$ & $1.83-1.85$ & $\mathbf{P}$ & $\mathrm{A}$ & $\mathrm{C}$ & $\mathrm{C}$ & $\mathrm{C}$ & & & & & & & & & & \\
\hline $1-3,70-72$ & $3.70-3.72$ & $\mathrm{P}$ & $\mathrm{R}$ & A & $\mathrm{C}$ & $\mathrm{C}$ & & & $\mathrm{R}$ & & & & & & & \\
\hline $14,75-77$ & $4.75-4.77$ & $\mathrm{P}$ & $\mathrm{R}$ & A & $\mathrm{C}$ & C & $\mathrm{R}$ & & $\mathrm{R}$ & & & & & & & \\
\hline $1, \mathrm{CC}$ & 5.00 & $\mathbf{P}$ & $\mathrm{A}$ & C & C & C & & & & & & & & & & \\
\hline $2-1,126-129$ & $6.26-6.29$ & $\mathrm{P}$ & $\mathrm{C}$ & A & C & C & $\mathrm{R}$ & $\mathbf{P}$ & $\mathbf{P}$ & & & $\mathbf{P}$ & & & & \\
\hline $2-2,126-129$ & $7.76-7.79$ & $\mathrm{P}$ & $\mathrm{C}$ & A & C & C & $\mathrm{R}$ & $\mathrm{P}$ & $\mathrm{R}$ & & & & & & & \\
\hline $2-3,123-126$ & $9.23-9.26$ & $\mathrm{P}$ & $\mathrm{C}$ & A & C & C & $\mathrm{R}$ & $\mathrm{P}$ & & & & $\mathbf{P}$ & & & & \\
\hline $2-4,109-112$ & $10.59-10.62$ & $\mathrm{P}$ & $\mathrm{C}$ & A & $\mathrm{C}$ & C & & & $\mathrm{R}$ & & & & & & & \\
\hline $2, \mathrm{CC}$ & 11.00 & $\mathrm{P}$ & $\mathrm{A}$ & $\mathrm{A}$ & $\mathrm{R}$ & C & & & & & & & & & & \\
\hline $3-1,123-125$ & $15.73-15.75$ & $\mathrm{P}$ & $\mathrm{C}$ & $\mathrm{A}$ & C & C & & $\mathbf{P}$ & $\mathrm{P}$ & & & & & & & \\
\hline $3-2,123-125$ & $17.23-17.25$ & $\mathrm{P}$ & $\mathrm{A}$ & $\mathrm{A}$ & C & C & $\mathrm{R}$ & & $\mathrm{R}$ & & & $\mathbf{P}$ & & & & \\
\hline $3-3,123-125$ & $18.73-18.75$ & $\mathrm{P}$ & $\mathrm{C}$ & $\mathrm{A}$ & C & A & $\mathrm{R}$ & & $\mathrm{R}$ & & & $\mathbf{P}$ & & & & \\
\hline $3-4,113-115$ & $20.13-20.15$ & $\mathrm{P}$ & $\mathrm{C}$ & $\mathrm{A}$ & C & $\mathrm{C}$ & & & & & & & & & & \\
\hline $3-5,135-138$ & $21.85-21.88$ & $\mathrm{P}$ & $\mathrm{A}$ & $\mathrm{A}$ & C & C & $\mathrm{R}$ & & $\mathrm{P}$ & & & & & & & \\
\hline $3-6,123-125$ & $23.23-23.25$ & $\mathrm{P}$ & $\mathrm{C}$ & A & C & C & $\mathrm{R}$ & & $\mathrm{R}$ & & & & & & & \\
\hline $3, \mathrm{CC}$ & 24.00 & $\mathrm{P}$ & $\mathrm{C}$ & $\mathrm{A}$ & C & C & $\mathrm{R}$ & $\mathrm{P}$ & $\mathrm{R}$ & & & & & & & \\
\hline $4-1,56-58$ & $24.56-24.58$ & $\mathrm{P}$ & $\mathrm{A}$ & $\mathrm{A}$ & C & C & $\mathrm{R}$ & & $\mathrm{P}$ & & & & & & & \\
\hline $4-2,126-128$ & $26.76-26.78$ & $\mathrm{P}$ & $\mathrm{C}$ & $\mathrm{A}$ & C & $\mathrm{C}$ & $\mathrm{R}$ & & $\mathrm{P}$ & & & & & & & \\
\hline $4-3,126-129$ & $28.26-28.29$ & $\mathrm{P}$ & $\mathrm{C}$ & $\mathrm{A}$ & C & $\mathrm{C}$ & $\mathrm{C}$ & & & & & & & & & \\
\hline $4-4,125-128$ & $29.75-29.78$ & $\mathrm{P}$ & $\mathrm{C}$ & $\mathrm{A}$ & C & C & $\mathrm{C}$ & & $\mathrm{R}$ & & $\mathrm{R}$ & $\mathrm{P}$ & & & & \\
\hline $4-5,54-57$ & $30.54-30.57$ & $\mathrm{P}$ & $\mathrm{C}$ & $\mathrm{A}$ & C & C & $\mathrm{C}$ & & $\mathrm{R}$ & & & & & & & \\
\hline $4-6,46-48$ & $31.96-31.98$ & $\mathrm{P}$ & $\mathrm{A}$ & A & C & C & $\mathrm{C}$ & & $\mathrm{R}$ & & & $\mathrm{P}$ & & & & \\
\hline $4, \mathrm{CC}$ & 33.50 & $\mathrm{P}$ & $\mathrm{C}$ & $\mathrm{A}$ & C & C & $\mathrm{C}$ & $\mathrm{P}$ & $\mathrm{R}$ & & & $\mathrm{P}$ & & & & \\
\hline $5-1,20-22$ & $33.70-33.72$ & $\mathrm{P}$ & $\mathrm{C}$ & $\mathrm{A}$ & $\mathrm{C}$ & C & $\mathrm{C}$ & & $\mathrm{R}$ & & & $\mathrm{P}$ & & & & \\
\hline $5-2,122-124$ & $36.22-36.24$ & $\mathrm{P}$ & $\mathrm{A}$ & A & $\mathrm{C}$ & C & $\mathrm{R}$ & & $\mathrm{P}$ & & & & & & & \\
\hline $5-3,122-124$ & $37.72-37.74$ & $\mathbf{P}$ & $\mathrm{C}$ & A & $\mathrm{C}$ & $\mathrm{C}$ & $\mathrm{R}$ & & $P$ & & & & & & & \\
\hline $5-4,23-25$ & $38.23-38.25$ & $\mathrm{P}$ & $\mathrm{C}$ & $\mathrm{A}$ & $\mathrm{C}$ & C & $\mathrm{C}$ & $\mathrm{P}$ & $\mathrm{P}$ & & & & & & & \\
\hline $5-5,122-124$ & $40.72-40.74$ & $\mathrm{P}$ & $\mathrm{C}$ & $\mathrm{A}$ & $\mathrm{C}$ & C & $\mathrm{R}$ & & $P$ & & & & & & & \\
\hline $5-6,22-24$ & $41.22-41.24$ & $\mathbf{P}$ & $\mathrm{C}$ & $\mathrm{A}$ & C & C & $\mathrm{C}$ & & P & & & & & & & \\
\hline $5, \mathrm{CC}$ & 43.00 & $\mathbf{P}$ & $\mathrm{R}$ & $\mathrm{A}$ & C & C & $\mathbf{P}$ & & $\mathrm{P}$ & & & & & & & \\
\hline $6-1,126-129$ & $44.26-44.29$ & $P$ & & $\mathrm{C}$ & C & C & $\mathrm{R}$ & & & & & & & & & \\
\hline $6-2,126-129$ & $45.76-45.79$ & $\mathrm{P}$ & $\mathrm{R}$ & $\mathrm{C}$ & C & C & $\mathrm{R}$ & & & & & $\mathbf{P}$ & & & & \\
\hline $6-3,125-127$ & $47.25-47.27$ & $P$ & $\mathrm{R}$ & $\mathrm{C}$ & C & $\mathrm{C}$ & $\mathrm{R}$ & & & & & & & & & \\
\hline $6-4,122-124$ & $48.72-48.74$ & $\mathrm{P}$ & $\mathrm{R}$ & $\mathrm{A}$ & C & C & $\mathrm{R}$ & & & & & & & & & \\
\hline $6-5,144-146$ & $50.44-50.46$ & $\mathrm{P}$ & $\mathrm{R}$ & $\mathrm{C}$ & C & $\mathrm{C}$ & $\mathrm{P}$ & & & & & & & & & \\
\hline $6-6,126-129$ & $51.76-51.79$ & $\mathrm{P}$ & $\mathrm{C}$ & $\mathrm{A}$ & C & C & $\mathrm{P}$ & & & & & & & & & \\
\hline $6, \mathrm{CC}$ & 52.50 & $\mathrm{P}$ & $\mathrm{R}$ & $\mathrm{A}$ & C & C & $\mathrm{P}$ & & & & & & & & & \\
\hline $7-1,120-123$ & $53.70-53.73$ & $P$ & $\mathrm{R}$ & $\mathrm{A}$ & C & C & $\mathrm{R}$ & & & & & & & & & \\
\hline $7-2,123-126$ & $55.23-55.26$ & $P$ & $\mathrm{C}$ & A & C & $\mathrm{C}$ & $\mathrm{P}$ & & $\mathrm{P}$ & & & & & & & \\
\hline $7-3,20-23$ & $55.70-55.73$ & $\mathbf{P}$ & $\mathrm{C}$ & A & C & C & $\mathrm{R}$ & & $\mathrm{R}$ & & & & & & & \\
\hline $7-4,50-52$ & $57.50-57.52$ & $\mathrm{P}$ & $\mathrm{R}$ & $\mathrm{A}$ & C & C & $\mathrm{R}$ & & C & & & & & & & \\
\hline $7-5,50-52$ & $59.00-59.02$ & $\mathbf{P}$ & $\mathrm{R}$ & C & C & C & $\mathrm{R}$ & & C & & & & & & & \\
\hline $7, \mathrm{CC}$ & 60.00 & $\mathbf{P}$ & $\mathrm{R}$ & C & C & C & $\mathrm{R}$ & & C & & & & & & & \\
\hline $8-1,50-52$ & $62.50-62.52$ & $\mathbf{P}$ & $\mathrm{R}$ & C & C & C & $\mathrm{R}$ & & $\mathrm{C}$ & & & $\mathrm{P}$ & & & & \\
\hline
\end{tabular}


TABLE 4 - Continued

\begin{tabular}{|c|c|c|c|c|c|c|c|c|c|c|c|c|c|c|c|}
\hline \multirow[b]{2}{*}{$\begin{array}{c}\text { Sample } \\
\text { (Interval in } \mathrm{cm} \text { ) }\end{array}$} & \multirow[b]{2}{*}{$\begin{array}{l}\text { Depth } \\
\text { Hole (m) }\end{array}$} & & \multicolumn{13}{|c|}{ Sediment Coarse Fraction Components } \\
\hline & & 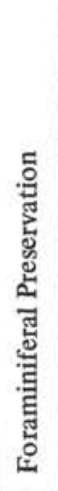 & 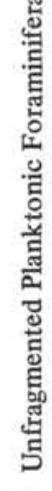 & 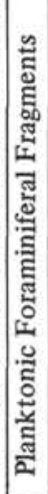 & 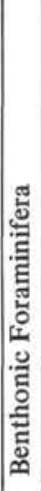 & 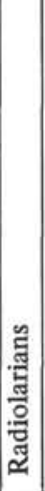 & 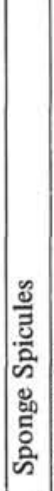 & 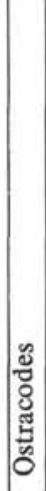 & 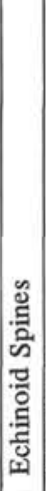 & 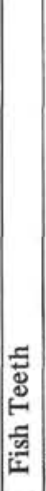 & 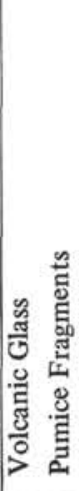 & 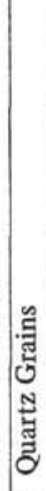 & गु르 & 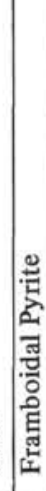 & 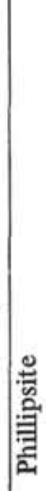 \\
\hline $8-2,50-52$ & $64.00-64.02$ & $\mathbf{P}$ & $\mathrm{C}$ & $\mathrm{C}$ & C & $\mathrm{C}$ & $\mathrm{R}$ & & $\mathrm{C}$ & & & & & $\mathrm{R}$ & \\
\hline $8-3,123-125$ & $66.23-66.25$ & $\mathrm{P}$ & $\mathrm{R}$ & C & $\mathrm{C}$ & $\mathrm{C}$ & $\mathrm{R}$ & & $\mathrm{C}$ & & $\mathbf{P}$ & & & $\mathrm{R}$ & \\
\hline $8-4,122-124$ & $67.72-67.74$ & $\mathrm{P}$ & $\mathrm{R}$ & $\mathrm{C}$ & $\mathrm{C}$ & $\mathrm{C}$ & $\mathrm{R}$ & & $\mathrm{R}$ & & 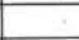 & & & $\mathrm{R}$ & \\
\hline $8-5,30-32$ & $68.30-68.32$ & $\mathbf{P}$ & $\mathrm{R}$ & C & C & $\mathrm{C}$ & $\mathrm{R}$ & & $\mathrm{C}$ & & & & & $\mathrm{R}$ & \\
\hline $8-6,131-134$ & $70.81-70.84$ & $\mathbf{P}$ & $\mathrm{C}$ & A & C & $\mathrm{C}$ & $\mathrm{R}$ & & $\mathrm{R}$ & & & & & & \\
\hline $8, \mathrm{CC}$ & 71.50 & $\mathrm{P}$ & $\mathrm{C}$ & A & C & $\mathrm{C}$ & $\mathrm{R}$ & & $\mathrm{R}$ & & & & & & \\
\hline $9-1,124-127$ & $72.74-72.77$ & $\mathbf{P}$ & $\mathrm{C}$ & A & C & $\mathrm{R}$ & C & & $\mathrm{C}$ & & & & & & \\
\hline $9-2,124-127$ & $74.24-74.27$ & $\mathrm{P}$ & $\mathrm{R}$ & A & C & $\mathrm{R}$ & C & & $\mathrm{R}$ & & $\mathbf{P}$ & & & & \\
\hline $9-3,51-53$ & $75.01-75.03$ & $\mathrm{P}$ & $\mathrm{R}$ & A & C & $\mathrm{R}$ & C & & $\mathrm{R}$ & & & & & & \\
\hline $9-4,50-51$ & $76.50-76.51$ & $\mathrm{P}$ & $\mathrm{R}$ & A & C & $\mathrm{R}$ & C & & C & $\mathrm{P}$ & $\mathrm{P}$ & & & & \\
\hline $9-5,50-52$ & $78.00-78.02$ & $\mathrm{P}$ & $\mathrm{C}$ & A & $\mathrm{C}$ & $\mathrm{R}$ & C & & $\mathrm{R}$ & & & & & & \\
\hline $9-6,50-52$ & $79.50-79.52$ & $\mathrm{P}$ & $\mathrm{C}$ & $\mathrm{A}$ & C & $\mathrm{R}$ & $\mathrm{R}$ & & $\mathrm{R}$ & $\mathrm{P}$ & & & & & C \\
\hline $9, \mathrm{CC}$ & 80.50 & $\mathrm{P}$ & $\mathrm{C}$ & A & C & $\mathrm{R}$ & $\mathrm{R}$ & & $\mathrm{P}$ & & & & & & 4 \\
\hline
\end{tabular}

Note: Components abundance: $\mathrm{A}$, abundant; $\mathrm{C}$, common; $\mathrm{R}$, rare; $\mathrm{P}$, present. Preservation: $\mathrm{G}$, good; $\mathrm{M}$, moderate; $\mathrm{P}$, poor.

to as $G$. miozea by Kennett, 1966) to $G$. conomiozea, to $G$. sphericomiozea (referred to as $G$. crassaformis by Kennett, 1966, and as G. puncticulata sphericomiozea by Kennett, 1973, and Kennett and Watkins, 1974), to G. puncticulata. Kennett and Watkins (1974) calibrated these evolutionary events to the paleomagnetic stratigraphy determined in New Zealand sections. Their paleomagnetic age assignments are as follows: first appearance of $G$. conomiozea (at the base of the Kapitean Stage of New Zealand) in the lower Gilbert reversed epoch, at about 4.7 m.y. B.P.; first appearance of $G$. sphericomiozea (at the upper boundary of the Kapitean Stage) between the Gilbert $c$ and the Nunivak events of the Gilbert, at about 4.3 m.y. B.P.; and the first appearance of $G$. puncticulata (simultaneously with the first appearance of $G$. crassaformis) at or close to the upper part of the Nunivak event of the Gilbert, at about 3.9 m.y. B.P.

The Mio-Pliocene boundary in New Zealand has been traditionally placed at the upper limit of the Kapitean Stage (at the boundary between the Kapitean and Opoitian stages) marked by the first appearance of the nonkeeled form $G$. sphericomiozea (which has been variously called $G$. inflata by Hornibrook, 1958, and Jenkins, 1967a; G. crassaformis by Kennett, 1966, 1967; and G. puncticulata by Kennett, 1973, Kennett and Watkins, 1972, Hornibrook and Edwards, 1971, and Collen and Vella, 1973). This boundary, dated by Kennett and Watkins (1974) at $4.3 \mathrm{~m} . y$. , thus appears to be younger than the type boundary between the Miocene and Pliocene in Italy placed at about 5.0 m.y. (Berggren, 1973; Berggren and Van Couvering, 1974). The base of the Kapitean Stage ( $4.7 \mathrm{~m} . \mathrm{y}$.) also appears to be younger than the type Mio-Pliocene boundary. A conflict, however, exists between the Pliocene paleomagnetic age of the Kapitean Stage and faunal correlations between the Kapitean and the late Miocene Messinian Stage of Italy. Although faunal correlations between the New Zealand and Mediterranean areas are particularly difficult because of the limited diversity of species found in New Zealand, and because these two areas had different paleooceanographic histories, the Kapitean and Messinian appear to be, at least in part, correlatable. This is suggested by the occurrence of the Kapitean index species G. conomiozea in the lower Messinian of Sicily (equals Sahelian) reported by Catalano and Sprovieri (1971).

Other areas where members of the G. miozea-G. inflata plexus have been reported include the temperate North Atlantic (Berggren, 1972a; Poore and Berggren, 1974, in press), the northeastern Pacific (Olsson, 1971), Japan (Ikebe et al., 1972), and the subtropical Indian Ocean (Bandy, in press). Data from these various geographic areas suggest that $G$. conomiozea first appears in the late Miocene. In Japan the $G$. conomiozea range starts questionably in N.17, spans the N.17/N.18 boundary, and ends above the first appearance of $G$. crassaformis and last appearance of "Globigerina" nepenthes at a level approximating the base of the range of Globo- 
TABLE 5

Sediment Coarse Fraction $(>63 \mu)$ Components and Foraminiferal Preservation at Site 313

\begin{tabular}{|c|c|c|c|c|c|c|c|c|c|c|c|c|c|c|c|c|}
\hline \multirow[b]{2}{*}{$\begin{array}{c}\text { Sample } \\
\text { (Interval in } \mathrm{cm} \text { ) }\end{array}$} & \multirow[b]{2}{*}{$\begin{array}{l}\text { Depth in } \\
\text { Hole (m) }\end{array}$} & \multirow[b]{2}{*}{ 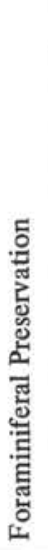 } & \multicolumn{14}{|c|}{ Sediment Coarse Fraction Components } \\
\hline & & & 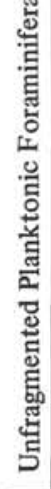 & 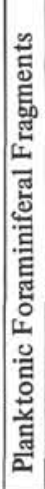 & 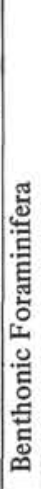 & 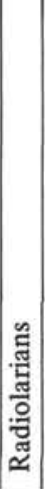 & 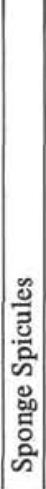 & 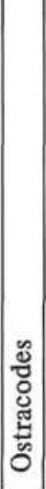 & 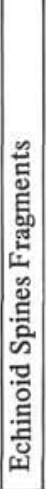 & 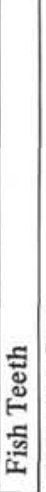 & 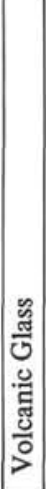 & 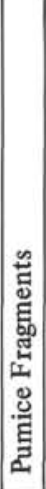 & 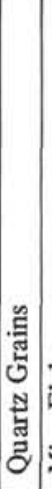 & 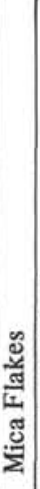 & 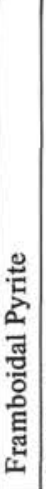 & 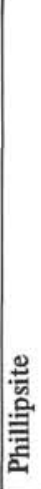 \\
\hline $1-1,100-102$ & $0.00-0.02$ & $\mathrm{P}$ & A & A & C & & & & & & & & & & & \\
\hline $1-1,131-134$ & $0.31-0.34$ & $\mathrm{P}$ & A & A & C & & & & & & & & & & & \\
\hline $1-2,18-21$ & $0.68-0.71$ & $\mathbf{P}$ & A & A & C & & & $\mathrm{P}$ & & & & & & & & \\
\hline $1-2,111-114$ & $1.51-1.54$ & $\mathrm{P}$ & $\mathrm{A}$ & A & C & & & $\mathrm{P}$ & & & & & & & & \\
\hline $1-3,31-34$ & $2.31-2.34$ & $\mathrm{P}$ & $\mathrm{A}$ & $\mathrm{A}$ & $\mathrm{C}$ & & & & & & & & & & & \\
\hline $1-3,120-123$ & $3.20-3.23$ & & & & & & & & & & & & & & $\mathrm{R}$ & \\
\hline $1-4,51-54$ & $4.01-4.04$ & $\mathrm{P}$ & $\mathrm{C}$ & A & $\mathrm{R}$ & & & $\mathrm{P}$ & & & & & & & $\mathrm{R}$ & \\
\hline $1-4,111-114$ & $4.61-4.64$ & $\mathbf{P}$ & $\mathrm{C}$ & A & $\mathrm{R}$ & & & $\mathrm{P}$ & & & & & & & $\mathrm{R}$ & \\
\hline $1-5,31-34$ & $5.31-5.34$ & $\mathrm{P}$ & $\mathrm{R}$ & C & $\mathrm{R}$ & & & $\mathbf{P}$ & & & & & & & $\mathrm{R}$ & \\
\hline $1-5,121-124$ & $6.21-6.24$ & $\mathrm{P}$ & $\mathrm{R}$ & $\mathrm{R}$ & $\mathrm{R}$ & & & & & $\mathrm{P}$ & & & & & $\mathrm{C}$ & \\
\hline $1-6,31-34$ & $6.81-6.84$ & $\mathrm{P}$ & & $\mathrm{R}$ & $\mathrm{R}$ & & & $\mathrm{P}$ & & & & & & & & \\
\hline $1-6,107-110$ & $7.57-7.60$ & $\mathrm{P}$ & $\mathrm{R}$ & $\mathrm{R}$ & $\mathrm{R}$ & & & $\mathrm{P}$ & & & & & & & $\mathrm{C}$ & \\
\hline $1, \mathrm{CC}$ & 8.00 & $\mathrm{P}$ & $\mathrm{R}$ & C & $\mathrm{R}$ & & & & & & & & & & C & \\
\hline $2-1,108-110$ & $36.58-36.60$ & $P$ & & $\mathrm{R}$ & $\mathrm{R}$ & & & & & & & & & & $\mathrm{C}$ & \\
\hline $2-1,143-146$ & $36.93-36.96$ & $\mathrm{P}$ & $\mathrm{C}$ & $\mathrm{A}$ & $\mathrm{R}$ & & & & & & & & & & & \\
\hline $2-2,56.59$ & $37.56-37.59$ & $\mathrm{P}$ & $\mathrm{R}$ & C & $\mathrm{R}$ & & & & & & & & & & & \\
\hline $2-2,121-124$ & $38.21-38.24$ & $\mathrm{P}$ & $\mathrm{C}$ & $\mathrm{A}$ & $\mathrm{R}$ & & & & & & & & & & & \\
\hline $2-3,41-44$ & 38.91-38.94 & $\mathrm{M}$ & $\mathrm{A}$ & $\mathrm{R}$ & & & & & & & & & & & & \\
\hline $2-3,121-124$ & $39.71-39.74$ & $\mathrm{P}$ & $\mathrm{R}$ & $\mathrm{C}$ & $\mathrm{R}$ & $\mathrm{C}$ & $\mathrm{C}$ & & & & & & & & & \\
\hline $2, \mathrm{CC}$ & 40.00 & $\mathbf{P}$ & $\mathrm{R}$ & $\mathrm{R}$ & & A & A & & & & & & & & & \\
\hline
\end{tabular}

Note: Components abundance: A, abundant; C, common; R, rare; $\mathrm{P}$, present. Preservation: $\mathrm{G}$, good; $\mathrm{M}$, moderate; $\mathrm{P}$, poor.

rotalia tosaensis (Ikebe et al., 1972, their fig. 3). It thus appears that $G$. conomiozea would span the PlioMiocene boundary in Japan. At DSDP Site 116 in the North Atlantic, G. conomiozea first occurs within the late Miocene Zone N.17 below a change in the coiling direction of Neogloboquadrina atlantica, which, in the high latitudes of the North Atlantic occurs at approximately the Mio-Pliocene boundary (Poore and Berggren, 1974, in press). Recent investigations on the southern flank of the Rio Grande Rise have revealed the presence of $G$. conomiozea within the foraminiferal Zone N.17 and lower nannoplankton zone Ceratolithus tricorniculatus Zone of Martini (NN.12, correlative to the Triquetrorhabdulus rugosus Subzone of Bukry), both indicative of the late Miocene (Berggren, personal communication).

Some discrepancies exist in the position of the extinction level of keeled members of the Globorotalia miozeainflata group reported by various authors. In the subtropical Indian Ocean, Bandy (in press) reported that in the paleomagnetically dated Core V20-163 (Hays et al., 1969), G. conoidea and G. conomiozea disappear essentially midway between the Cochiti event of the Gilbert and the base of the Gauss (about 3.5 m.y.). This paleomagnetic age is somewhat younger than the paleomagnetic age of 4.3 m.y. reported by Kennett and Watkins (1974) for the extinction of G. conomiozea in New Zealand, and older than the age of $3.0 \mathrm{~m} . y$. estimated from biostratigraphic correlations for the youngest occurrence of G. conoidea by Poore and Berggren (1974) and Olsson (1971) in the North Atlantic and northeast Pacific, respectively.

Berggren and Amdurer (1973) discussed lineages of this important planktonic group, the correlations between different areas, and plotted the various evolutionary events against a time-scale framework (their fig. 10). Their age assignments for various datums are as follows-first appearance of G. conoidea: 11.9 m.y.; first appearance of $G$. sphericomiozea: 6.0 m.y.; first appearance of $G$. puncticulata: 4.5 m.y.; extinction of $G$. 
TABLE 6

Neogene Planktonic Foraminifera Distribution at Site 305

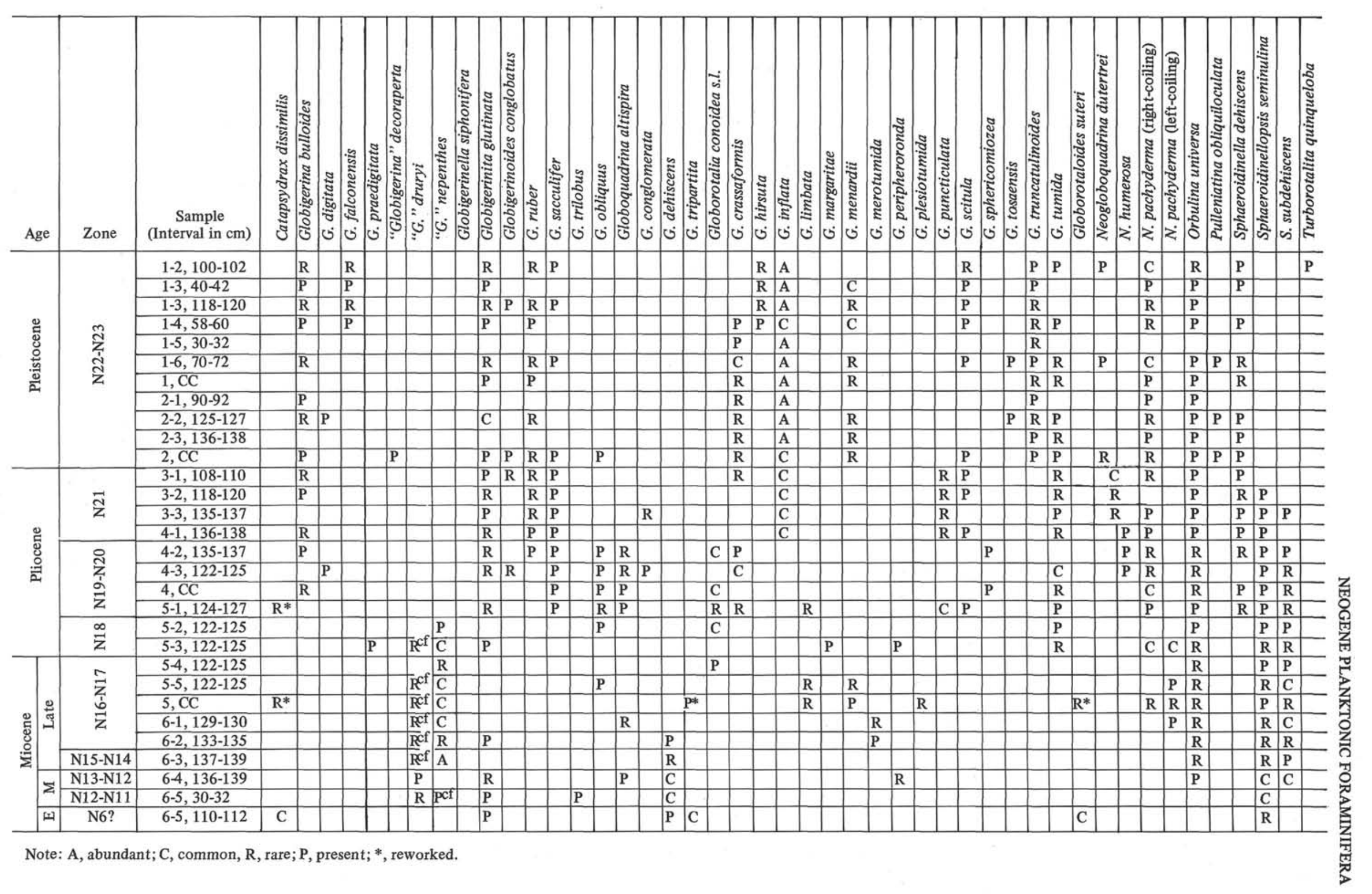




\begin{tabular}{|c|c|c|c|c|c|c|c|c|c|c|c|c|c|c|c|c|c|c|c|c|c|c|c|c|c|c|c|c|c|c|c|}
\hline Age & Zone & $\begin{array}{c}\text { Sample } \\
\text { (Interval in } \mathrm{cm} \text { ) }\end{array}$ & 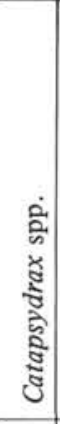 & 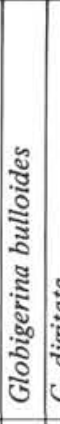 & 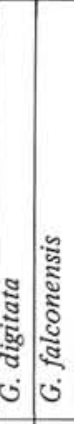 & 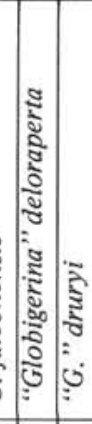 & 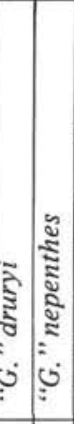 & 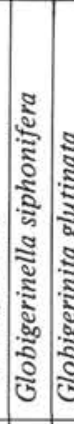 & 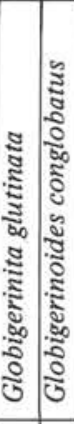 & 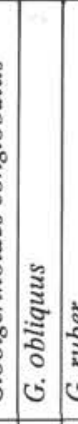 & 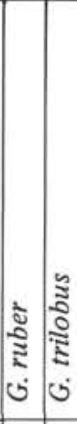 & 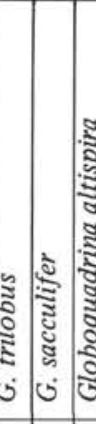 & 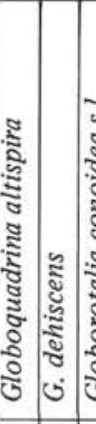 & 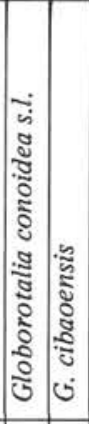 & 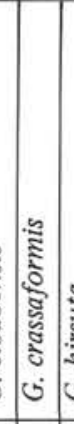 & 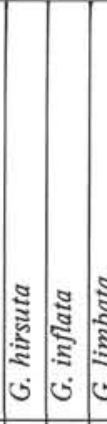 & 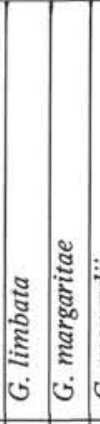 & 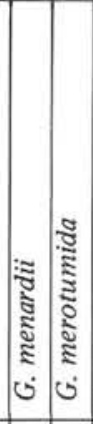 & 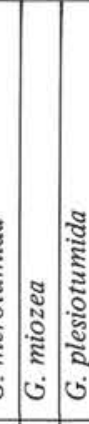 & 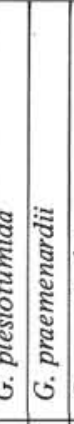 & 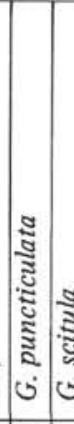 & 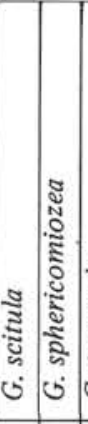 & ن & 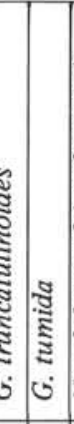 & 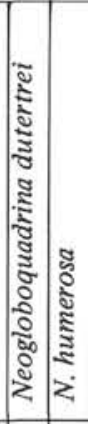 & 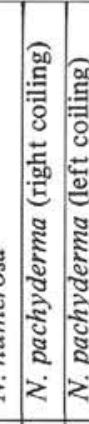 & 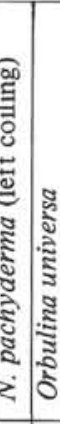 & 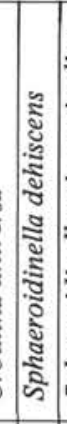 & 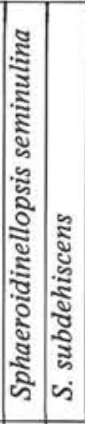 & 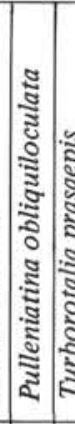 & 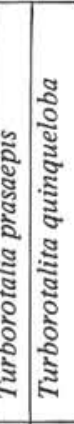 \\
\hline \multirow{16}{*}{ 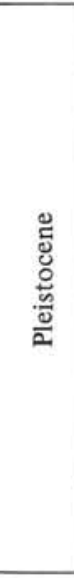 } & \multirow{16}{*}{$\begin{array}{l}\tilde{\tilde{z}} \\
\text { त̃ } \\
\tilde{z}\end{array}$} & $1-1,5-7$ & & $\mathrm{C}$ & P & & & & $\mathrm{R}$ & & P & $\mathrm{P}$ & & & & C & & & & & & & $\mathrm{R}$ & $\mathrm{R}$ & & $\mathrm{A}$ & $\mathrm{R}$ & & & & $\mathbf{P}$ \\
\hline & & $1-2,33-35$ & & C & $\mathrm{P}$ & & & & $\mathrm{R}$ & & $\mathrm{R}$ & & & & & \begin{tabular}{|l|l|}
$R$ & $C$ \\
\end{tabular} & & & & & & & & & & \begin{tabular}{l|l}
$\mathrm{A}$ & $\mathrm{R}$ \\
\end{tabular} & \begin{tabular}{|l|l}
$\mathrm{R}$ & $\mathrm{R}$ \\
\end{tabular} & & & & $\mathrm{R}$ \\
\hline & & $1-3,70-72$ & & $\mathrm{R}$ & & & & & 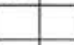 & & O & & & & 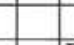 & $\begin{array}{ll}\text { C } \\
\end{array}$ & & & & & & & $\mathrm{R}$ & R & & \begin{tabular}{l|l} 
C \\
\end{tabular} & $\mathrm{R}$ & & & & \\
\hline & & $14,75-77$ & & & & & & & & & & & & & & \begin{tabular}{|l|l} 
P & A \\
\end{tabular} & & & & & & & & & & $\mathrm{P}$ & & & & & 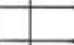 \\
\hline & & $1, \mathrm{CC}$ & & \begin{tabular}{l|l}
$R$ & $P$ \\
\end{tabular} & & & & \begin{tabular}{l|l}
$\mathrm{P}$ & $\mathrm{R}$ \\
\end{tabular} & $\mathrm{R}$ & & $\mathrm{R}$ & & & & \begin{tabular}{l|l}
$R$ & $F$ \\
\end{tabular} & \begin{tabular}{|l|l|}
$P$ & $C$ \\
\end{tabular} & & $R$ & & & & & & & & $\mathrm{~A}$ & & $\mathrm{P}$ & & $\mathbf{P}$ & 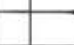 \\
\hline & & $2-1,126-129$ & & \begin{tabular}{l|l}
$R$ \\
\end{tabular} & & & & & \begin{tabular}{l|l}
$\mathrm{R}$ & $\mathrm{P}$ \\
\end{tabular} & & $\mathrm{R}$ & & & & \begin{tabular}{l|l} 
& 1 \\
\end{tabular} & \begin{tabular}{|l|l|}
$\mathrm{R}$ & $\mathrm{A}$ \\
\end{tabular} & & & & & & & $\mathbf{P}$ & P & & $\mathrm{C}$ & $\mathrm{P}$ & & & & \\
\hline & & $2-2,126-129$ & & P & & & & & & & & & & & \begin{tabular}{|l|} 
P \\
\end{tabular} & $\begin{array}{ll}\text { C } \\
\end{array}$ & & 1 & & & & & & & & + & $\mathrm{P}$ & & & & 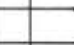 \\
\hline & & $2-3,123-126$ & & $\mathrm{P}$ & & & & & 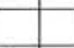 & & & & & & $\mathrm{R}$ & C & & 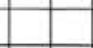 & & & & & 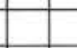 & & P & $\mathbf{P}$ & 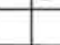 & + & & & \\
\hline & & $24,109-112$ & & $\mathrm{R}$ & & & & & $\mathrm{P}$ & & P & & & & $\mathrm{R}$ & C & & & & & & & 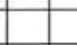 & 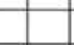 & & C & & & & & \\
\hline & & $2, \mathrm{CC}$ & & $\mathrm{R}$ & & & & & & & & & & & $\mathrm{R}$ & $\mathrm{A}$ & & $\mathrm{R}$ & & & & & & & & C & $\mathbf{P}$ & $\mathrm{P}$ & & & \\
\hline & & $3-1,123-125$ & & $\mathrm{P}$ & & & & & - & & 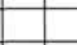 & & & & $\mathrm{R}$ & C & & & & & & & & & 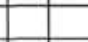 & \begin{tabular}{l|l|l}
$\mathrm{R}$ & $\mathrm{R}$ \\
\end{tabular} & R & & & & \\
\hline & & $3-2,123-125$ & & $\mathrm{R}$ & & & & & 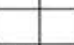 & & 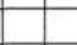 & & & & $\mathrm{P}$ & A & & & & & & & $\mathbf{R}$ & $\mathrm{R}$ & & \begin{tabular}{l|l}
$\mathrm{R}$ & $\mathrm{R}$ \\
\end{tabular} & \begin{tabular}{|l|l}
$\mathrm{R}$ & $\mathrm{R}$ \\
\end{tabular} & & & & \\
\hline & & $3-3,123-125$ & & $\mathrm{R}$ & & & & & $\mathbf{P}$ & & & & & & & C & & & & & & & $\vec{P}$ & P & & $\mathrm{R}$ & & & & & \\
\hline & & $3-4,113-115$ & & $P$ & & & & & $\mathrm{P}$ & & & & & & 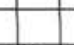 & C & & & & & & & 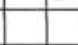 & 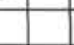 & & $\mathrm{R}$ & 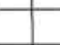 & & & & \\
\hline & & $3-5,135-138$ & & A & & & & & $\mathrm{R}$ & & $\mathrm{P}$ & & & & C & A & & & & & & & 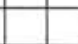 & & P & $\mathrm{R}$ & & & & & P \\
\hline & & $3-6,123-125$ & & $\mathrm{R}$ & P & & & & $\mathrm{P}$ & & $\mathrm{P}$ & & & & $\mathrm{R}$ & $\mathrm{C}$ & & & & & & & \begin{tabular}{|l|l}
$P$ & $P$ \\
\end{tabular} & \begin{tabular}{ll|}
$\mathrm{P}$ & $\mathrm{R}$ \\
\end{tabular} & $\mathrm{R}$ & C & $\mathrm{R}$ & & $P$ & & $\mathrm{P}$ \\
\hline \multirow{19}{*}{ 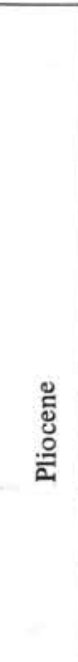 } & \multirow{14}{*}{$\bar{z}$} & $3, \mathrm{CC}$ & & $\mathrm{R}$ & & & & & $\mathrm{P}$ & & & & & & $P$ & C & & & & & & & P & $\mathbf{P}$ & $\mathrm{R}$ & C & $\mathrm{R}$ & & $P$ & & \\
\hline & & $4-1,56-58$ & & $\mathrm{R}$ & & & & & \begin{tabular}{l|l}
$\mathrm{R}$ & $\mathrm{P}$ \\
\end{tabular} & & $\mathrm{P}$ & & & & $\mathrm{P}$ & A & & & & & & & & $\mathbf{P}$ & C & $\mathrm{R}$ & $\mathrm{R}$ & & $\mathbf{P}$ & & \\
\hline & & $4-2,126-128$ & & $\mathrm{R}$ & & & & & \begin{tabular}{|l|l}
$\mathrm{P}$ & $\mathrm{P}$ \\
\end{tabular} & & $\mathrm{P}$ & & & & $\mathrm{R}$ & C & & & & & & & & $\mathbf{P}$ & C & $\mathrm{R}$ & & $\mathrm{P}$ & & & \\
\hline & & $4-3,126-129$ & & & & & & & & & & & & & & C & & & & & & & & $\mathbf{P}$ & $\mathrm{R}$ & 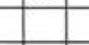 & P & & & & \\
\hline & & $4-4,125-128$ & & P & & & & & $\mathrm{P}$ & & & & & & $R$ & $\mathrm{R}$ & & & & & & & & $\mathbf{P}$ & $\mathrm{C}$ & 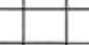 & $\mathbf{P}$ & & & & \\
\hline & & $4-5,54-57$ & & P & & & & & & & $\mathrm{P}$ & & & & C & C & & & & & & & & & C & 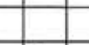 & & & & & \\
\hline & & $4-6,46-48$ & & C & & & & & $\mathbf{R}$ & & & & & & 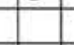 & C & & & & & $\mathrm{R}$ & & & $\mathbf{P}$ & $R$ & P & 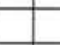 & & & & \\
\hline & & $4, \mathrm{CC}$ & & $\mathrm{P}$ & & & & & $\mathrm{P}$ & & $\mathrm{P}$ & & & & 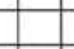 & C & & & & & $\mathrm{R}$ & & & $\mathrm{P}$ & & P & P & & & & \\
\hline & & $5-1,20-22$ & & P & & & & & \begin{tabular}{l|l|}
$\mathrm{P}$ & $\mathrm{P}$ \\
\end{tabular} & & & & & & & C & & & & & $\mathrm{R}$ & & & $\mathbf{P}$ & $\mathrm{C}$ & & $\overline{\mathbf{P}}$ & & & & \\
\hline & & $5-2,122-124$ & & $\mathrm{R}$ & & & & & $R$ & & P & & & & P & A & & & & & $\mathrm{R}$ & & & $\mathbf{P}$ & C & $\mathbf{P}$ & P & & & & \\
\hline & & $5-3,122-124$ & & $P$ & & & & & & & & & & & $P$ & C & & & & & C & & & $\mathrm{R}$ & & & $\mathrm{R}$ & $\mid \mathrm{P}$ & 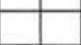 & & \\
\hline & & $5-4,23-25$ & & P & & & & & $\mathbf{P}$ & & & & & & & C & & & & & C & & & $\mathrm{P}$ & P & & & & & & \\
\hline & & $5-5,122-124$ & & P & & $\mathrm{P}$ & & & & & & & & & $P$ & $R$ & & & & & C & & & & $\mathbf{P}$ & 5 & & & C & & \\
\hline & & $5-6,22-24$ & & $\mathrm{P}$ & & & & & $\mathbf{P}$ & & & & & & $\mathrm{P}$ & P & & & & & C & P & & $R$ & P & 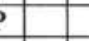 & & & $\mathrm{C}$ & & \\
\hline & \multirow{5}{*}{$\begin{array}{l}\text { ্ָ } \\
\text { ż. } \\
\vec{z}\end{array}$} & $5, \mathrm{CC}$ & & & & & & & $\mathrm{P}$ & & & & & & $\mathrm{R}$ & & & & & & $\mathrm{R}$ & $\mathbf{P}$ & & & & & $\mathrm{R}$ & & $R$ & & \\
\hline & & $6-1,126-129$ & & & & & & & & & & & & & & & & & & & & & & & & & & & & & \\
\hline & & $6-2,126-129$ & & & & & & & & & & & & $\mathrm{R}$ & $\mathrm{R}$ & & & & & & $\mathrm{P}$ & $\mathbf{P}$ & & & $\mathbf{P}$ & 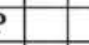 & $\mathbf{P}$ & & & & \\
\hline & & $6-3,125-127$ & & & & & & & & & & & & $\mathrm{R}$ & $\mathrm{R}$ & & & & & & & $\mathrm{P}$ & & & & & P & & $\mathbf{P}$ & & \\
\hline & & $6-4,122-124$ & & $\mid \mathbf{R}$ & 1 & & & & \begin{tabular}{|l|l|}
$R$ & \\
\end{tabular} & $\left.\right|_{\mathrm{F}}$ & $P$ & $|\mathbf{R}|$ & & & $|\vec{C}|$ & 11 & & & & & & $\mid \mathbf{P}$ & & $\mathbf{P}$ & & & & & & & \\
\hline
\end{tabular}




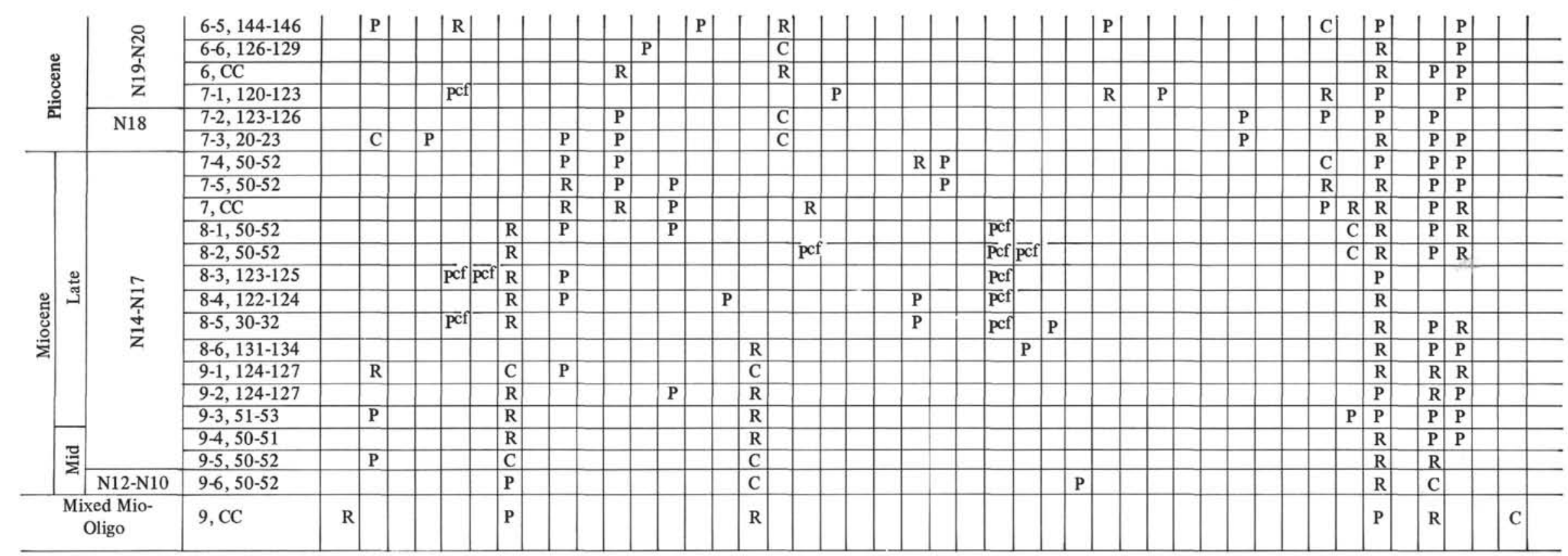

Note: $\mathrm{A}$, abundant; $\mathrm{C}$, common; $\mathrm{R}$, rare; $\mathrm{P}$, present. 
TABLE 8.

Neogene Planktonic Foraminifera Distribution at Site 313

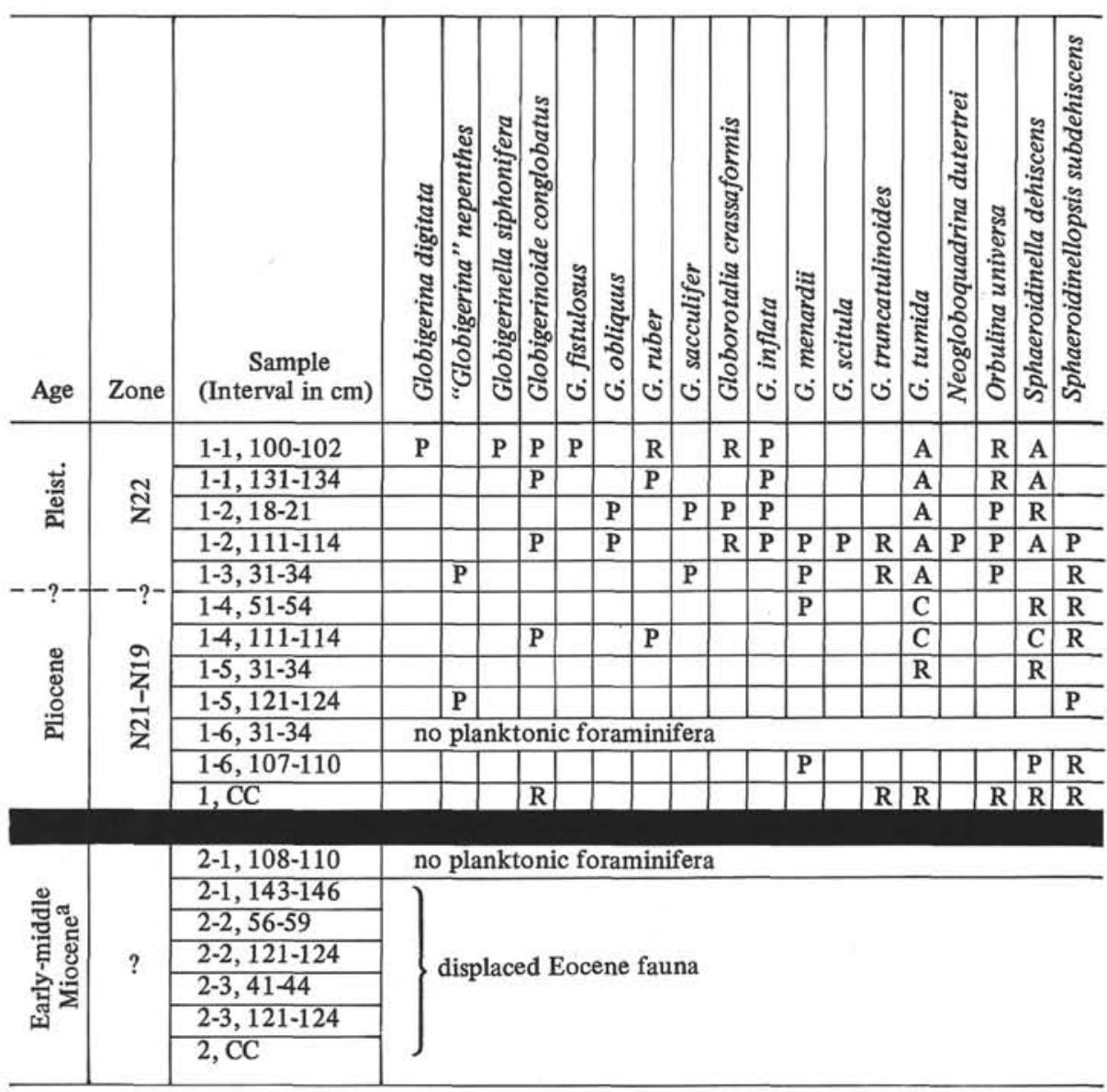

Note: A, abundant; $\mathrm{C}$, common; $\mathrm{R}$, rare; $\mathrm{P}$, present.

${ }^{\mathrm{a}} \mathrm{Based}$ on nannofossil and radiolarian data.

conoidea and of $G$. sphericomiozea together with the first appearance of $G$. inflata: $3.0 \mathrm{~m}$.y. The first appearance of $G$. crassaformis, which they consider a descendant of $G$. sphericomiozea, occurred $3.5 \mathrm{~m} . \mathrm{y}$. ago. The appearance and extinction of $G$. conomiozea, which they treat as part of a different lineage leading to Globorotalia crassula, are 6.0 and 3.0 m.y. ago, respectively.

Forms of the Globorotalia conoidea-inflata complex are consistent elements of the late Neogene Shatsky and Hess rise sections. Their stratigraphic range is plotted on Figures 2 and 3 against the nannofossil and radiolarian zonations and the stratigraphic range of other diagnostic planktonic foraminifera.

Individuals referable to $G$. conoidea in this material are usually heavily encrusted. A keel, however, even when buried, is always distinguishable. Highly conical typical forms of Globorotalia conomiozea were not found. However, Kennett and Watkins (1974) suggested that a cline exists in $G$. conomiozea with a cooler more conical phenotype grading into warmer water less conical phenotype and that the bioseries differs with latitude. As a result, populations of $G$. conomiozea reported by these authors in the Mangapoike River section of New Zealand "closely resemble G. miozea conoidea but differ in having an average of four and one- half chambers in the final whorl compared with five chambers in G. miozea conoidea" (Kennett and Watkins, 1974 , p. 1390). A low conical form of $G$. conomiozea (which Kennett recognized to be within the concept of his species) occurs in the subtropical Indian Ocean (Bandy, in press). Therefore, it is possible that forms of $G$. conomiozea that closely resemble $G$. conoidea are present in the material of the present study. However, because of the difficulty of counting chambers in encrusted forms, and because the time limitation for this report did not allow time-consuming faunal counts, no attempt was made to differentiate $G$. conomiozea from $G$. conoidea, which is referred here to G. conoidea s.l. Large populations of $G$. conoidea s.l. abruptly appear at both Sites 305 and 310 at the Mio-Pliocene boundary. As will be discussed later, this sudden appearance resulted from the elimination of the species and its forerunner G. miozea by increased calcium carbonate dissolution below this level.

Forms referable to unkeeled $G$. sphericomiozea are very rare. They are small, compact, circular to oval in shape and heavily encrusted. Globorotalia puncticulata and $G$. crassaformis first occur in the same horizon at both sites. This level also coincides with the lowest occurrence of Sphaeroidinella dehiscens at Site 305. In the 


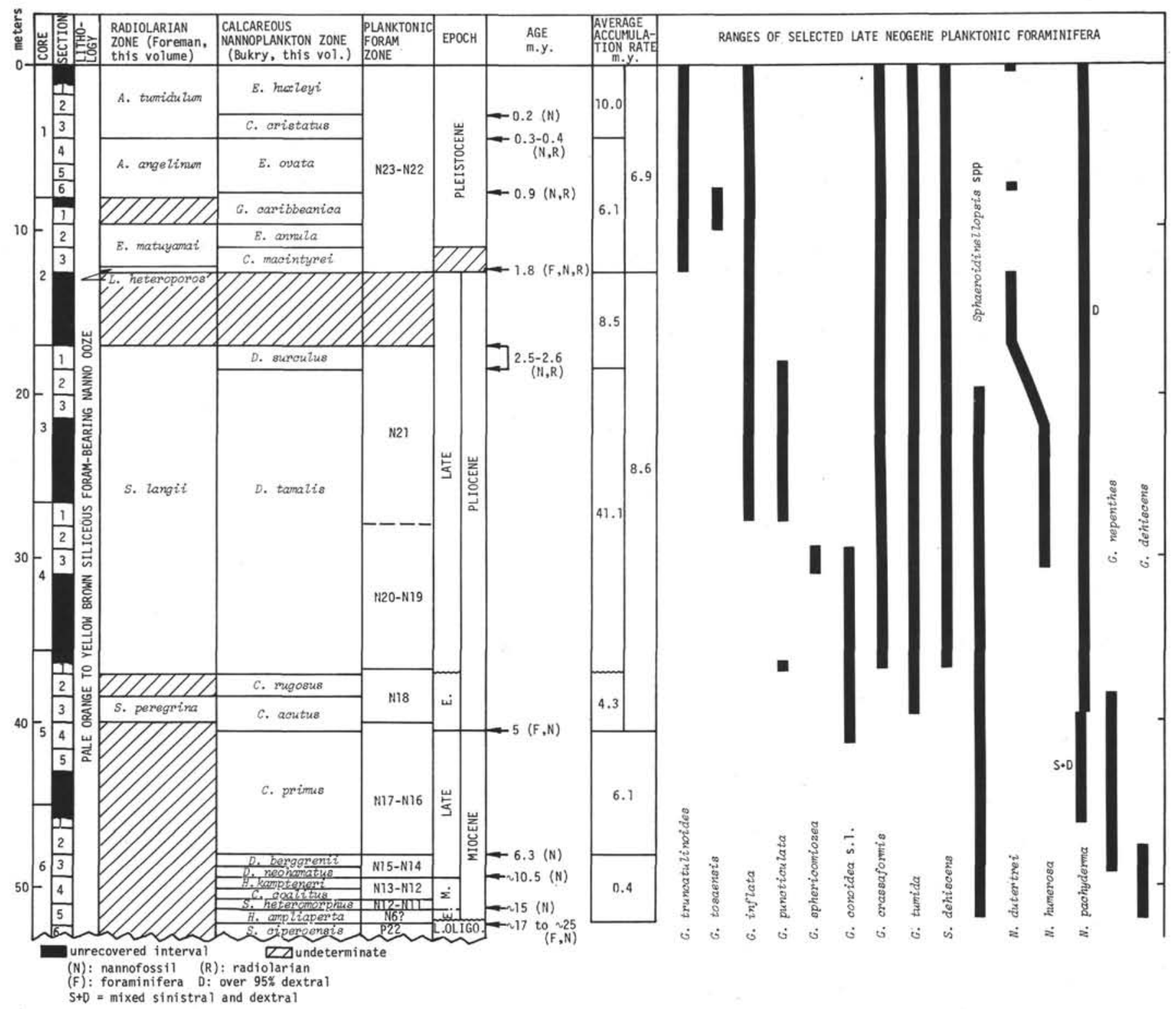

Figure 2. Neogene planktonic biostratigraphy at Site 305.

absence of the latter taxon at Site 310, the N.19/N.18 zonal boundary was tentatively placed at the lowest occurrence of $G$. crassaformis and G. puncticulata. Globorotalia conoidea is subordinate to $G$. puncticulata at both sites when the latter species first appears, but then $G$. conoidea-dominated populations occur until forms transitional between $G$. puncticulata and $G$. inflata occur commonly. Populations of $G$. inflata first occur in the middle of the section correlating with the Discoaster tamalis Zone. The first occurrence of $G$. inflata was tentatively used here to define the base of Zone N.21 because $G$. inflata is known to evolve elsewhere at approximately the same time as $G$. tosaensis, and the later zonal taxon was absent. Primitive forms of $G$. inflata with four chambers and a rather quadrate equatorial outline are gradually replaced by forms with three and one-half to three chambers and a more rounded outline. Typical modern populations of $G$. inflata with a highly glossy

wall first appear at both sites near the Plio-Pleistocene boundary.

Globorotalia crassaformis first appears at both Sites 305 and 310 in the same horizon as G. puncticulata. The former species exhibits a wide range of morphologic variations throughout the sections. These include variations in the size of the test, the degree of the conical angle of the test (ventral convexity), the tightness of coiling, the shape and depth of the umbilical area, the peripheral acuteness and the degree of incrustation (Plate 3, Figures 1-14). No subspecies names were used to differentiate the different morphotypes because many of these variations are probably ecologically controlled (Lidz, 1972). Certain variations in shell morphology of G. crassaformis appear to be contemporaneous at both Sites 305 and 310 and provide a correlation (Figure 6). Populations of large specimens, loosely coiled, with a wide-open umbilicus (Plate 3, Figure 7) were found in 


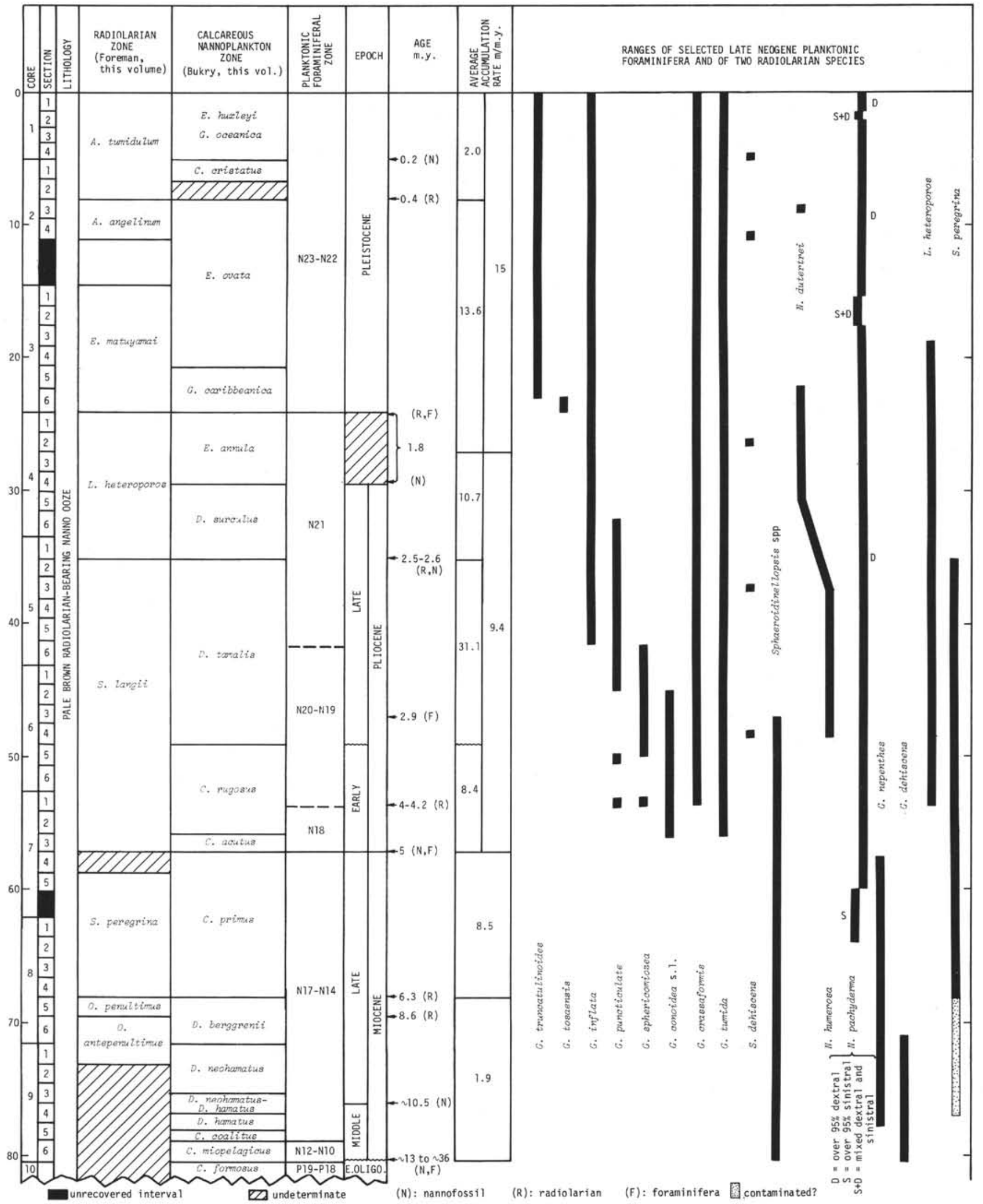

Figure 3. Neogene planktonic biostratigraphy at Site 310. 
NEOGENE PLANKTONIC FORAMINIFERA

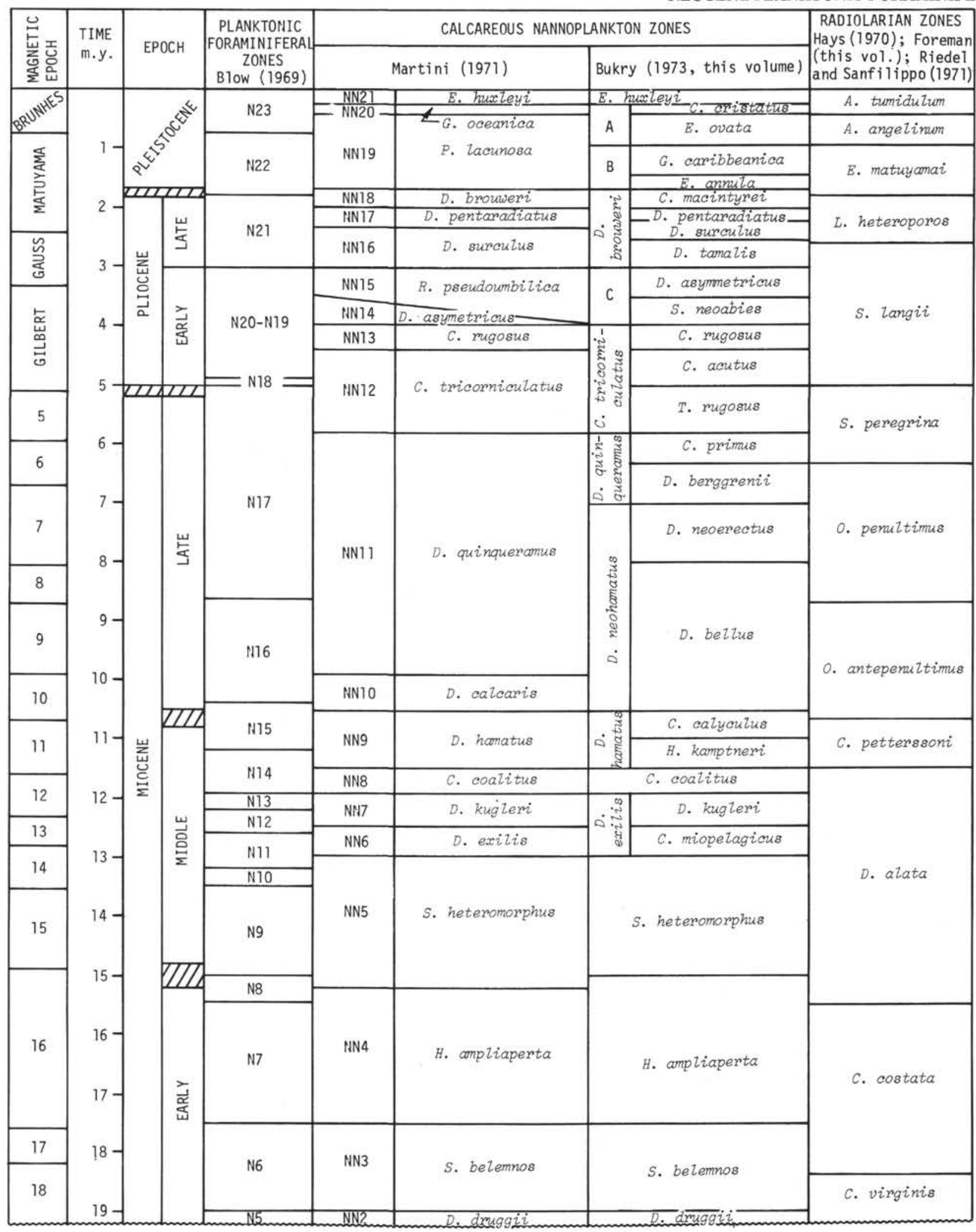

A) G. oceanica

B) C. doronicoides

Figure 4. Time relationship and correlation of Neogene planktonic microfossil zones. The correlation of Blow's (1969) planktonic foraminiferal zones with those of Martini (1971) for calcareous nannoplankton and the assignment of absolute ages to the zone boundaries are from Berggren (1973) and Van Couvering and Berggren (in press). The calcareous nannoplankton zonal scheme of Bukry $(1973$, this volume) is correlated to Martini's zonation. The radiolarian zonation utilized here employs the zonal schemes developed by Hays (1970) for the Pleistocene and late Pliocene and by Riedel and Sanfilippo (1971) for the Miocene, which have been both calibrated to the paleomagnetic scale (Hays, 1970; Theyer and Hammond, 1974). A new early Pliocene radiolarian zone is defined by Foreman (this volume) for the North Pacific where the Spongaster pentas Zone of Riedel and San Filippo (1971) is not represented. See references for generic abbreviations. 


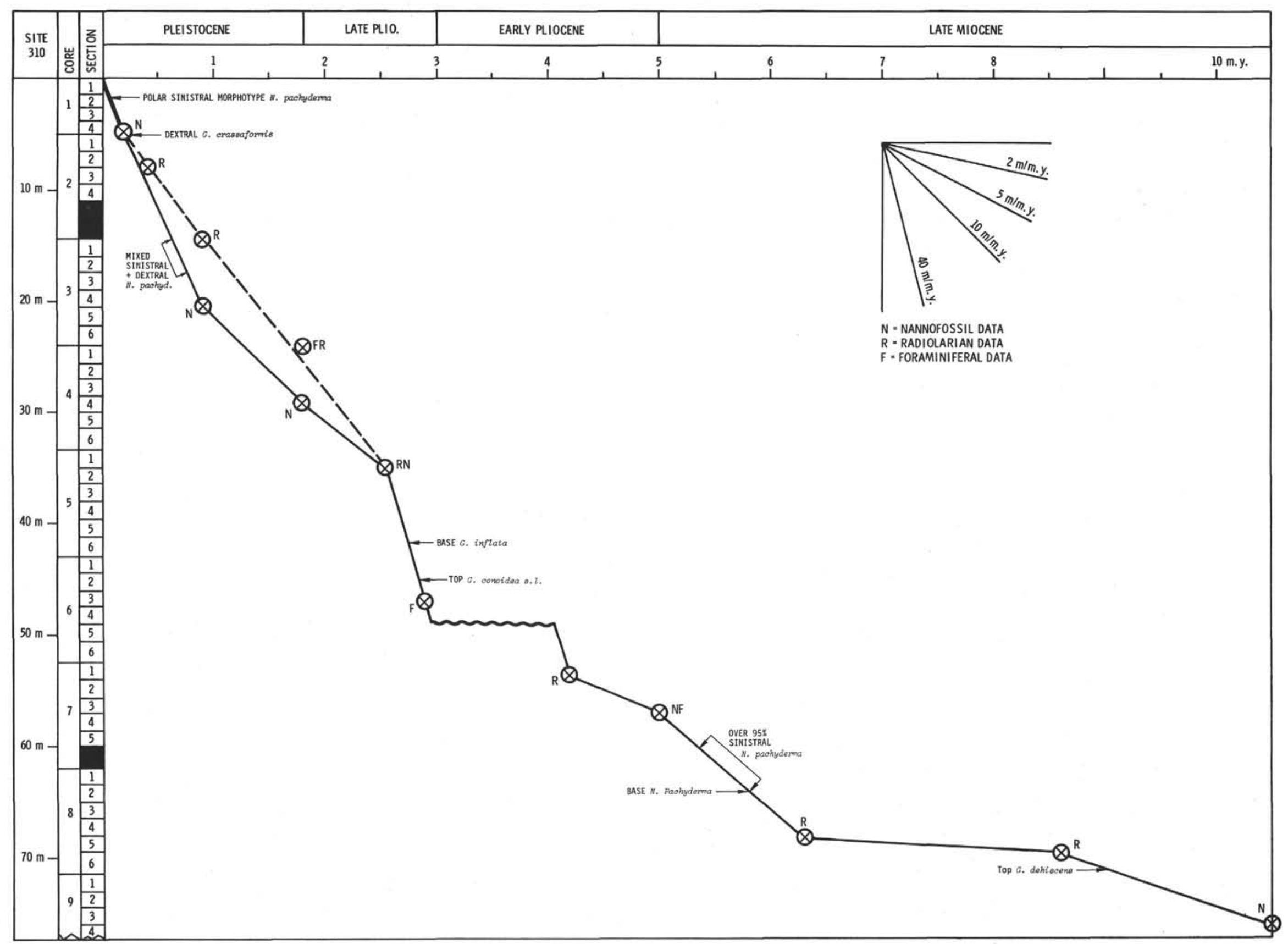

Figure 5. Average accumulation rates of late Neogene sediments at Sites 305 and 310. 


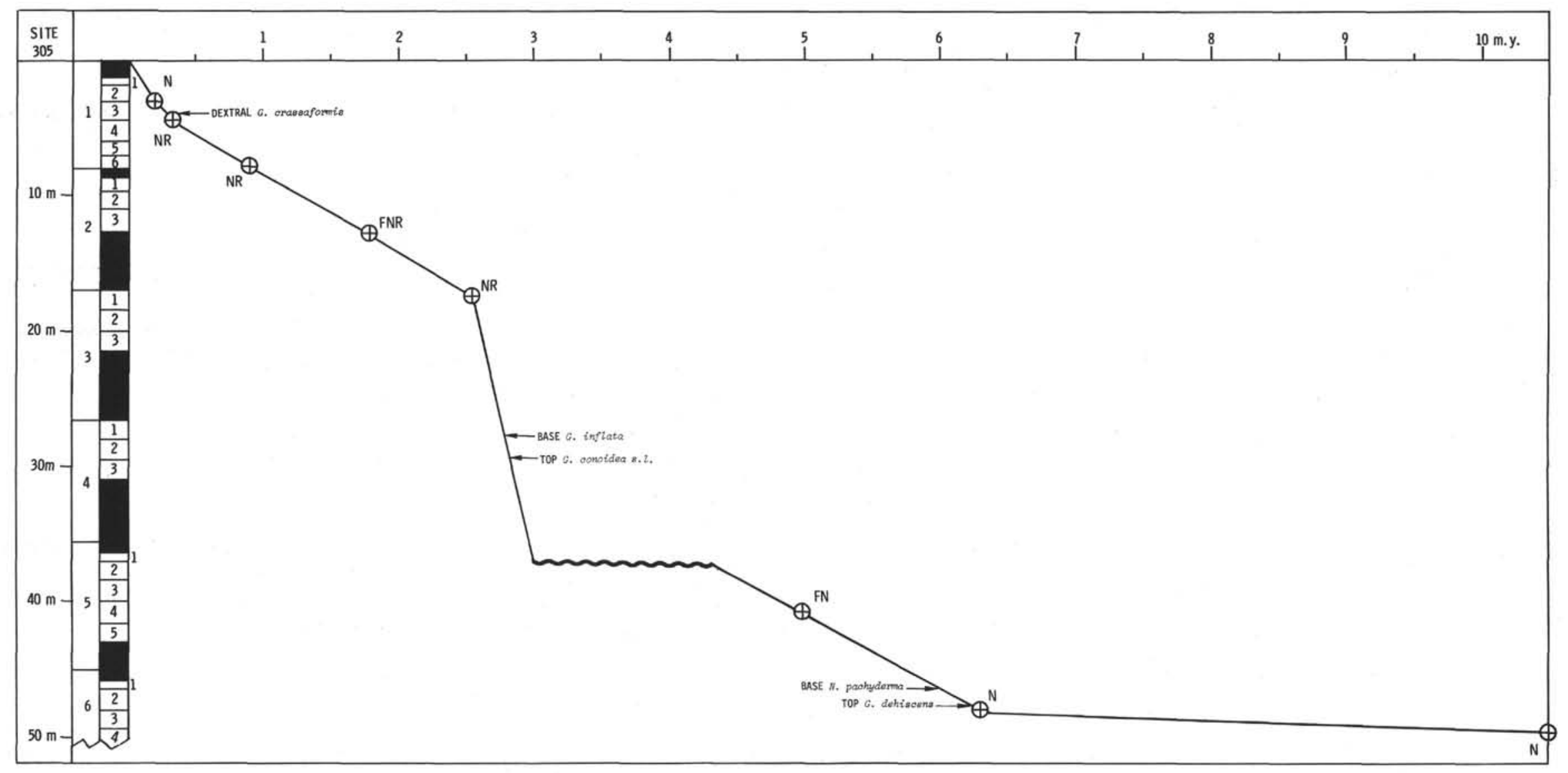

Figure 5. (Continued). 


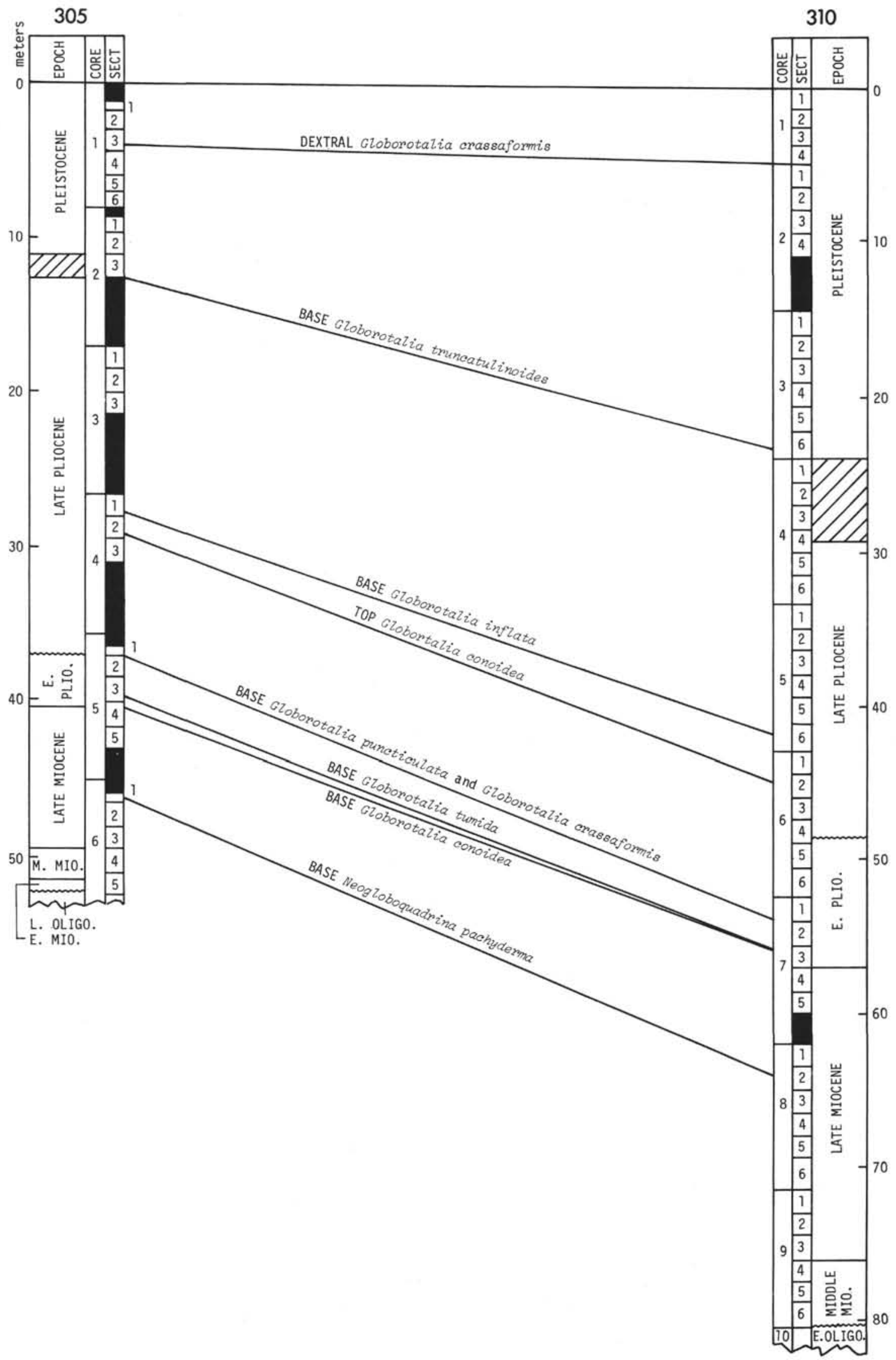

Figure 6. Correlation of late Neogene planktonic foraminiferal events between Sites 305 and 310. 
the basal Pleistocene, and an interval with dextrally coiled populations occurs in the late Pleistocene, about 0.3 m.y. ago based on sedimentation rate estimates.

The development of Neogloboquadrina dutertrei from $N$. humerosa is another evolutionary sequence of biostratigraphic importance. The transition from an umbilical-extraumbilical aperture to an umbilical aperture is broad and difficult to pinpoint, but occurs at both Sites 305 and 310 within the upper Pliocene at the same level reported by Parker $(1967,1973)$ in the tropical Pacific and tropical Atlantic. Populations referred to as $N$. humerosa and $N$. dutertrei in the present study, however, are not typical tropical ones. They lack umbilical teeth and are dominated by four chambered forms. End member specimens of these populations which have a rather closed umbilicus, the umbilical face of the final chamber which extends over the first chamber of the final whorl, and an incipient lip, are within the range of right-coiling Neogloboquadrina pachyderma ${ }^{1}$ and have been treated as such by a number of authors (Ingle, 1967; Kennett 1968a, b; Bandy and Ingle, 1970).

A multitude of opinions exists as to the taxonomic and stratigraphic position of $N$. pachyderma and to its relationship to the $N$. humerosa- $N$. dutertrei complex. Forms referred to as $N$. pachyderma in this report are consistently smaller than forms treated as $N$. humerosa and $N$. dutertrei. They are more compact and usually have an apertural lip. The fact that populations of small $N$. pachyderma and larger $N$. humerosa- $N$. dutertrei both occur in the same sample (e.g. Plate 4, Figure 14 and Plate 5, Figures 9-11) supports their separation. As pointed out by Parker and Berger (1971) and Ingle $(1973 a, b)$, regardless of the specific nature of these forms, coiling studies have repeatedly demonstrated their preferential coiling habit and their usefulness as paleoclimatic indicators.

The first evolutionary appearance of $N$. pachyderma from its ancestor $N$. continuosa (Jenkins, 1971; Bandy, 1972b), termed by Bandy the "Turborotalia pachyderma datum," is recognized in circum North Pacific sections near the foraminiferal zonal boundary N.12/N.13 (Bandy, 1972a, 1972b; Bandy et al., 1969; Bandy and Ingle, 1970; Parker, 1964; Ingle, 1967, 1973a; Ikebe et al., 1972). The delayed appearance of this temperate species here within N.17 (lower Ceratolithus primus nannofossil Zone) may result from a change in the degree of dissolution. N. humerosa first appears in Shatsky and Hess rise sections well above its known level of evolutionary appearance from its ancestor Neogloboquadrina acostaensis in N.18 in the tropical Pacific (Parker, 1967) and $N$. dutertrei virtually disappears abruptly at the Plio-Pleistocene boundary. Because of the uncertainty of the taxonomic position of four-chambered morphotypes of the $N$. humerosa-dutertrei group and of their

\footnotetext{
'The generic assignment Neogloboquadrina is made here for pachyderma, humerosa, and dutertrei species which are closely related and descend from $N$. continuosa. Neogloboquadrina morphologically is like Globoquadrina but developed from a different lineage and is, therefore, genetically unrelated to Globoquadrina (Bandy, et al., 1967).
}

ecological preferences, no attempt is made to interpret the delayed appearance of $N$. humerosa and the early disappearance of $N$. dutertrei in this area.

Planktonic foraminiferal events useful for Pliocene biostratigraphy and calibrated in the equatorial Pacific to the paleomagnetic scale (Hays et al., 1969; Saito et al., in press) include the evolutionary appearance of Sphaeroidinella dehiscens (4.8 m.y. B.P.) and the extinctions of Globoquadrina dehiscens (5.0 m.y. B.P.), "Globigerina" nepenthes (3.7 m.y. B.P.), Globorotalia margaritae (3.4 m.y. B.P.), Sphaeroidinellopsis spp., and Globoquadrina altispira (both 2.9 m.y. B.P.). Berggren (1973) used these data to develop his Pliocene time-scale framework. Datum planes may vary from low to high latitudes because of the water-mass dependence of planktonic foraminifera. Elimination of key species by selective dissolution is another factor which may hamper biostratigraphic correlations. Sites 305 and 310 are located in an area intermediate between subtropical and temperate waters, below the lysocline, and it is not always evident if the disappearance of a diagnostic species is an effect of dissolution, temperature, or a true extinction level. The key Pliocene species mentioned above, however, are relatives of modern dissolution-resistant species (Berger, 1968, 1970, 1971). Although the species "Globigerina" nepenthes is usually assigned to the dissolution-susceptible genus Globigerina, this species has a cancellate surface-wall texture (Plate 4, Figure 9) quite distinct from spinose Globigerina and belongs to a group which has apparently undergone an evolutionary development distinct from Globigerina (Fleisher, 1974). This species appears to be resistant to dissolution from its association with other robust forms in poorly preserved samples.

Globoquadrina altispira and Globorotalia margaritae are of no value in Shatsky and Hess rise sections, because none of the former and only a few of the latter species were found in the sections. It is not known whether their absence is a latitudinal or a dissolution effect.

The disappearance at both sites of Globoquadrina dehiscens is associated with the late Miocene cooling, which is reflected by the presence of sinistral populations of $N$. pachyderma, at a time much earlier than that of its known extinction in the equatorial Pacific. Kennett (1968b) and Kennett and Watkins (1974) pointed out that the extinction of $G$. dehiscens in New Zealand was controlled mainly by paleooceanographic cooling, the level of last occurrence of this species decreasing in age from south to north in response to progressive cooling. The later disappearance of $G$. dehiscens at the warmer water Site 305 (in the lowermost Discoaster berggrenii Zone) than at Site 310 (in the lowermost Ceratolithus primus Zone) probably results from a similar latitudinal effect.

The last occurrence of "Globigerina" nepenthes at Site 310 coincides with a lower Pliocene hiatus, which probably truncated its range. At Site 305 , however, this species disappears at the Mio-Pliocene boundary. This earlier disappearance at Site 305 probably does not result from increased dissolution because there is evidence (discussed later) of lesser dissolution above the 
boundary. It may reflect the latitudinal difference between the two sites. This hypothesis is not supported, however by the extinction of " $G$." nepenthes at $40^{\circ} \mathrm{N}$ latitude in the northeast Pacific at about the same time as in the equatorial region (Olsson, 1971).

Sphaeroidinellopsis spp. and Sphaeroidinella dehiscens are never important contributors to the Pliocene faunas from Shatsky and Hess rises, but their occurrences are more consistent at the warmer water Site 305. Sphaeroidinellopsis spp. last occur within the lower Discoaster tamalis nannofossil Zone at Site 310, just below the top of the range of Globorotalia conoidea. The age of this level, estimated from accumulation rates (Figure 5), agrees well with the paleomagnetic age of 2.9 m.y. for the extinction of this species in the tropics. Sphaeroidinellopsis spp., however, range higher up in the section at Site 305, well above the first occurrence of Globorotalia inflata and the Discoaster tamalis/Discoaster surculus zonal boundary. The high range of $S$. spp. here may result from reworking or contamination because only rare and sporadic specimens were found in the upper part of Core 4 and Core 3.

The base of the range of Sphaeroidinella dehiscens coincides at both Sites 305 and 310 with a minor hiatus, marked by a floral break. This hiatus prevents the calibration of the first occurrence of this species in this area to other faunal events. $S$. dehiscens, however, does not range as far down as Globorotalia puncticulata and $G$. crassaformis, both of which first occur below the hiatus at Site 310 , and it does not range down into the lower Ceratolithus rugosus and the Ceratolithus acutus zones. The first occurrence of $S$. dehiscens in this region of the North Pacific is stratigraphically higher than its known evolutionary appearance in the equatorial Pacific in the lowermost Gilbert epoch (4.8 m.y.) very close to the Mio-Pliocene boundary (Saito et al., in press; Berggren, 1973). Differences in paleooceanographic conditions may account for variations in the stratigraphic range of this species at various latitudes. Kennett reported a delayed first appearance of $S$. dehiscens in the temperate to subtropical latitudes of the southwest Pacific and pointed out that the first appearance of $S$. dehiscens varies between different water masses. Specimens of $S$. dehiscens with a small secondary aperture on the dorsal side were found in the lower part of its range in the present material. However, no individual was found with a minute needlepoint aperture surrounded by a rim-like lip which is typical of the "forma immatura" as illustrated by Poore and Berggren (1974, their pl. 3, fig. 1, 4).

\section{DATE ASSIGNMENTS AND RATES OF SEDIMENT ACCUMULATION}

The suggested absolute ages given in Figures 2 and 3 are inferred from selected planktonic faunal and floral zonal boundaries or datum planes, which have been directly, or indirectly (by biostratigraphic correlation), radiometrically paleomagnetically dated. These data points were used to construct curves of average sediment accumulation rates and, in turn, to estimate the age of selected planktonic foraminiferal events (Figure 5).

Pleistocene ages, indicated by the boundaries between the three youngest nannofossil and radiolarian zones (or subzones), are in general agreement. A discrepancy exists between the Emiliania ovata/Gephyrocapsa caribbeanica and the Axoprunum angelinum (= Stylatractus universus)/Eucyrtidium matuyamai zonal boundaries, both estimated to be 0.9 m.y. (Figure 4). These two boundaries coincide at Site 305 , but at Site 310 the nannofossil data indicate a lower position in the section for this time horizon. The nannofossil zonation also indicates a lower position for the 1.8-m.y. time horizon (Plio-Pleistocene boundary) at Site 310 than is indicated by radiolarian and foraminiferal data. The Pleistocene horizon with dextrally coiled Globorotalia crassaformis appears to be approximately $0.2-0.3 \mathrm{~m} . \mathrm{y}$. old. The average accumulation rate for the entire Pleistocene section on Shatsky Rise is about $7 \mathrm{~m} / \mathrm{m} . \mathrm{y}$. and on Hess Rise is $15 \mathrm{~m} / \mathrm{m} . \mathrm{y}$. However, sediments appear to have accumulated faster in late Pleistocene than in early Pleistocene.

The Stichocorys peregrina extinction datum, which defines the top of the Sphaeropyle langii Zone of Foreman (this volume) and the base of the Lamprocyclas heteroporos Zone of Hays (1970), is a very reliable worldwide datum for the late Pliocene at about 2.5-2.6 m.y. in the latest Gauss normal epoch (Hays et al., 1969; Hays, 1970; Kobayashi et al., 1971; Bandy et al., 1972; Theyer and Hammond, 1974). This radiolarian event coincides with the position of the Discoaster surculus/Discoaster tamalis nannofossil zonal boundary (also equated to 2.5 m.y.; Figure 4) at Site 310 and is slightly above the latter at Site 305 . These two radiolarian and nannofossil events provide an excellent time horizon at both Sites 305 and 310 and allow a calculated average rate of deposition of $8.5 \mathrm{~m} / \mathrm{m}$.y. for uppermost Pliocene sediments at Site 305 and $10.7 \mathrm{~m} / \mathrm{m}$.y. for Site 310 , values comparable to lower Pleistocene rates.

The base of the Globorotalia inflata range, preceded 2 to 4 meters lower in the sections by the top of the range of $G$. conoidea s.l., occurs within the Discoaster tamalis Zone at both Sites 305 and 310 and is slightly above the top of Sphaeroidinellopsis spp. at Site 310. The base of the $D$. tamalis Zone is estimated to be $3.0 \mathrm{~m}$.y. old, but, because of a floral break, its lower boundary cannot be identified here with certainty. It is probable, however, that this nannofossil zone is entirely represented at Site 310 where the highest occurrence of $S$. spp. suggests a 2.9-m.y. date for the $47 \mathrm{~m}$ horizon (Core 6, Section 3). Based on these data, a $31 \mathrm{~m} / \mathrm{m}$.y. rate of accumulation is estimated for the Pliocene section between 35 and 47 meters at Site 310 and the base of $G$. inflata and top of $G$. conoidea ranges are in turn estimated to be about 2.7 and $2.8 \mathrm{~m}$.y. old, respectively. It appears that $G$. inflata may have migrated into the North Pacific slightly later than elsewhere. In other areas typically this species first appeared $3.0 \mathrm{~m} . \mathrm{y}$. ago, before the extinction of Sphaeroidinellopsis spp., at a level approximating the Reticulofenestra pseudoumbilica/Discoaster surculus (NN.15/NN.16) nannofossil zonal boundary of Martini (1971) (Poore and Berggren, 1974; Berggren and Amdurer, 1973). This later appearance is supported by data from the northeastern Pacific DSDP Sites 36 and 173 where $G$. inflata also first appears above the extinction of Sphaeroidinellopsis spp. (Olsson, 1971, his fig. 2; Ingle, 1973a). An apparent conflict with this conclusion 
is shown by the extension of the range of Sphaeroidinellopsis spp. in upper Core 3 at Site 305 above the base of $G$. inflata. However, the rare and sporadic occurrences of Sphaeroidinellopsis spp. in upper Core 4 and Core 3 at Site 305 are thought to be due to contamination or reworking.

Globorotalia puncticulata and $G$. crassaformis first appear at Site 310 simultaneously with the radiolarian Lamprocyclas heteroporos within the Ceratolithus rugosus nannofossil Subzone of Bukry. The latter (correlative to Zone NN.13 of Martini) has been shown by calibration to the paleomagnetic scale to span the interval of time from 3.9 to 4.4 m.y. (Gartner, 1973). Casey (in press) suggested that tropical submergent radiolarians exhibit fairly consistent datum planes of a more or less cosmopolitan nature and believed that $L$. heteroporos exhibited this type of distribution. The earliest appearance of $L$. heteroporos has been recorded in cores dated by paleomagnetism just above the Gilbert b event in the equatorial Pacific (Casey, in press), and within or slightly below this magnetic event in cores from higher latitudes (Theyer, 1973; Hays, 1970). The earliest appearance of $L$. heteroporos coincides with the first occurrence of $G$. puncticulata and $G$. crassaformis in the northeast Pacific, as well, at DSDP Site 173 (Ingle, 1973a; Kling, 1973). In land sections from Southern California, $L$. heteroporos first appears within the Capistrano Formation (Delmontian Stage) at Newport Bay (Kling, personal communication) in an interval barren of foraminifera and slightly below the first occurrence of $G$. puncticulata, $G$. crassaformis, and $S$. dehiscens (Ingle, 1967, 1972) and within the Malaga Mudstone (Delmontian) at Malaga Cove (Casey, 1972; Casey et al., 1972). Fission-track dating of glass shards from waterlain beds of volcanic ash in the Malaga Mudstone yielded dates of 4.42 m.y. and 3.64 m.y. for the upper and lower Malaga Mudstone (Boellstorf and Steineck, 1974). All these data support a 4.0 to 4.2 m.y. date for the Lamprocyclas heteroporos datum, which in turn dates the first appearance of $G$. puncticulata and $G$. crassaformis in the Hess Rise section.

The lowest stratigraphic occurrences of Sphaeroidinella dehiscens, Globorotalia puncticulata, Globorotalia crassaformis and Lamprocyclas heteroporos, all of which are approximately simultaneous in temperate latitude sections of the North Pacific, have been taken as indicating the Mio-Pliocene boundary (Delmontian/Repettian stages) by California workers (Ingle, 1967, 1973a, b; Bandy and Ingle, 1970; Bandy, 1972a, b; Casey, 1972, in press). This level, associated with a paleooceanographic event, is easily recognized and may be a convenient position for placement of a boundary, but is stratigraphically higher than the $5.0-$ m.y. type Mio-Pliocene boundary (Berggren, 1973; Berggren and Van Couvering, 1974).

Estimates of average rates of accumulation on Shatsky and Hess rises show that rates were not constant during the Pliocene. An abrupt change in sedimentation occurred at about 2.5 m.y. Sediments were deposited 3 to 5 times faster between approximately 2.5 and 3.0 m.y. than during the latest Pliocene. A 1 to 1.3 m.y. period of nondeposition encompasses the Spheno- lithus neoabies and Discoaster asymmetricus nannofossil zones and also truncates the top of the Ceratolithus rugosus Zone at Site 305. The overall average rate of accumulation for the entire Pliocene interval is $8.6 \mathrm{~m} / \mathrm{m} . \mathrm{y}$. at Site 305 and $9.4 \mathrm{~m} / \mathrm{m} . y$. at Site 310 . From an examination of the curves constructed in Figure 5, one is tempted to draw a straight line between the 2.5 and 5.0 m.y. data points. This would eliminate the indentation of the curves. The inferred change in sedimentation regime, however, is probably real, as evidenced by floral and faunal breaks.

Two dates in the late Miocene section at Site 310 are obtained from the Stichocorys peregrina/Ommatartus penultimus and $O$. penultimus $/ O$. antepenultimus radiolarian zonal boundaries, paleomagnetically dated at 6.2 to 6.3 and 8.6 to 8.7 m.y., respectively (Theyer and Hammond, 1974). These data indicate an average accumulation rate of $8.5 \mathrm{~m} / \mathrm{m} . \mathrm{y}$. for the uppermost 11 meters of Miocene sediments at Site 310 and $0.7 \mathrm{~m} / \mathrm{m} . \mathrm{y}$. for the interval covered by Core 8 , Section 5 . A date of 6.3 m.y. assigned to the 48-meter horizon at Site 305 at the Ceratolithus primus/Discoaster berggrenii zonal boundary (correlative to the Stichocorys peregrina/Ommatartus penultimus boundary at Site 310 ) indicates an average accumulation rate of approximately $6 \mathrm{~m} / \mathrm{m}$.y. for the uppermost 8 meters of Miocene sediments at this site.

The early Neogene sections (early late Miocene, middle and early Miocene) are condensed at both Sites 305 and 310 . Dates of approximately 10.5 and 13 m.y. B.P. are respectively assigned, at Site 310 , to the late/middle Miocene boundary, based on the nannofossil zonation, and to the lowermost Neogene sample (Coccolithus miopelagicus Zone and N.10-N.12). These data indicate an average accumulation rate of $1.9 \mathrm{~m} / \mathrm{m} . \mathrm{y}$. for the lower 12.5 meters of Neogene sediments which unconformably overlie sediments of early Oligocene age. The latter, which are attributed to the Coccolithus formosus nannofossil Zone (Bukry, this volume), and the foraminiferal zonal interval P.19-P.18 (Fleisher, this volume), were deposited approximately 36 m.y. ago (Berggren, 1972). The stratigraphic gap between the Neogene and Paleogene sequences in the area of Site 310, therefore, spans an interval of about 23 m.y.

Early Neogene average rates of accumulation at Site 305 are even more reduced. The entire interval older than 6.3 m.y. has a calculated rate of $0.4 \mathrm{~m} / \mathrm{m}$.y. Lower Miocene sediments overlie upper Oligocene sediments from the Sphenolithus ciperoensis and P.22 zones. A gap of roughly 8 m.y. separates the Neogene and Paleogene sections in the southern part of Shatsky Rise. This hiatus is considerably shorter than the one at nearby Site 47 where upper Miocene sediments lie unconformably upon those of Eocene age (Fischer et al., 1971; Krasheninnikov, 1971).

The Neogene/Paleogene unconformity is marked at both Sites 305 and 310 by a sudden occurrence of abundant phillipsite crystals in the coarse fractions of the lowest Neogene samples (Tables 3 and 4).

The oldest occurrence of Neogloboquadrina pachyderma, estimated at approximately 5.8-5.9 m.y., is contemporaneous at both Sites 305 and 310, but Globo- 
quadrina dehiscens disappeared earlier at Site 310 (about 9 m.y. ago) than at Site 305 (about 6.3 m.y. ago) (Figure $5)$.

\section{PALEOOCEANOGRAPHY}

Assemblages of planktonic foraminifera from the highest sample recovered at Sites 305,310 , and 313 reflect the environment of the overlying surface water masses as well as the position of a shallow lysocline in the North Pacific. Those dissolution-resistant species of the modern transitional fauna (Bradshaw, 1959; Berger, 1968, 1970; Parker and Berger, 1971) dominate the assemblages at Sites 305 and 310 , whereas at Site 313 dissolution-resistant species of the modern subtropical fauna make up the assemblage (Table 2). The degree of fragmentation and the relative frequency of benthonic foraminifera (Table 2) correspond to the dissolution facies 6 of Berger and Von Rad (1972) which suggests a loss of foraminiferal carbonate of about $90 \%$.

Nonfragmented planktonic foraminifera are common to abundant in the coarse fraction (Tables 3 and 4 ) in that part of the section higher than a level approximating the base of the Globorotalia inflata range (Cores 1 to 3, Section 2 at Site 305, and Cores 1 to 5 at Site 310). However, dissolution facies remain at a value of 6 . Below that level the greater than $63 \mu \mathrm{m}$ fraction is very small, the abundance of nonfragmented planktonic foraminifera decreases, fragmentation is more pronounced, and the relative frequency of benthonic foraminifera increases. Dissolution facies reach a value of 7 (8 in a few horizons). An increased concentration of echinoid spine fragments and fish teeth in the coarse fraction of the lower part of the section below the MioPliocene boundary probably reflects an even greater degree of dissolution.

The abrupt appearance of Globorotalia conoidea, a temperate species well within its latitudinal range in the Shatsky and Hess rise areas, appears to be an effect of dissolution. This species is common when it first appears at the Mio-Pliocene boundary, well above its known evolutionary appearance. Below that level, however, numerous fragments of globorotaliid tests occur, which probably belong to this species (Plate 2, Figures 22-24). The level that separates nonfragmented populations of G. conoidea from entirely fragmented assemblages could be called the "Globorotalia conoidea lysoline." The appearance of the temperate to subarctic species Neogloboquadrina pachyderma in latest Miocene, later than its first evolutionary appearance in circum North Pacific areas, may also result from a change in dissolution intensity.

The apparent decrease in dissolution at both Sites 305 and 310 in the latest Miocene is probably correlated with the abrupt drop of the CCD at that time in equatorial regions of the Pacific (Figure 7; Berger, in press; van Andel and Moore, 1974).

Intense calcium carbonate dissolution during Miocene time is evident at Site 313 as well, although only scanty data for biostratigraphic or paleooceanographic interpretations were obtained. The lower part of Core 1 and uppermost Core 2, of late and middle Miocene age, respectively, yielded an extremely small amount of coarse fraction comprised mainly of benthonic foraminifera and framboidal pyrite (Table 5).

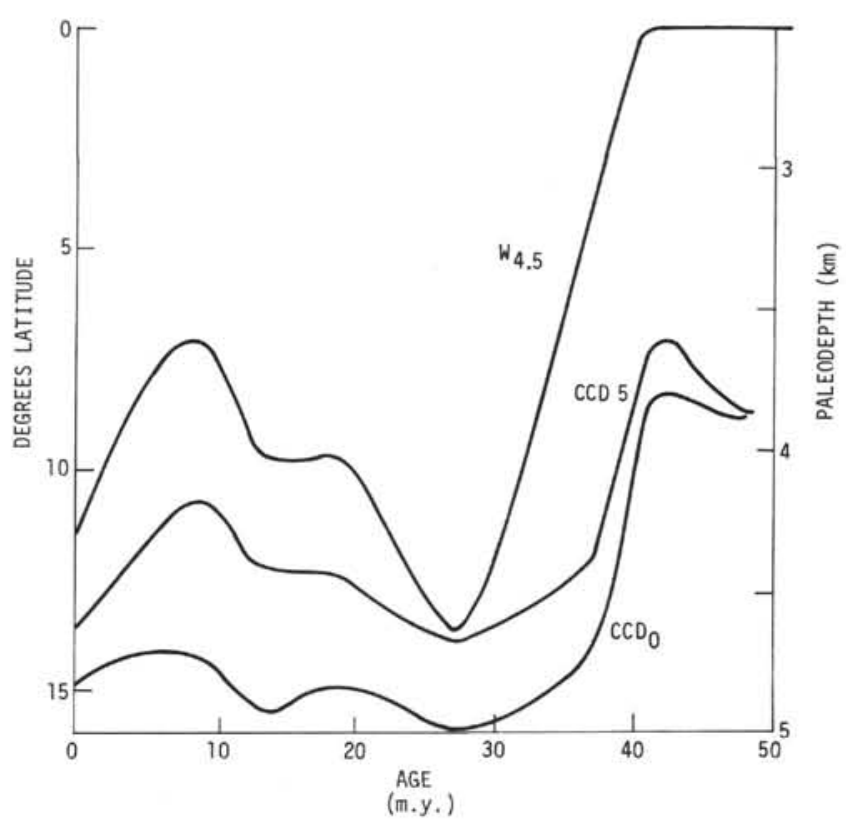

Figure 7. Fluctuations of the $C C D$ at the equator $\left(C C D_{0}\right)$ and at $5^{\circ} \mathrm{N}$ and $\mathrm{S}$ combined $\left(C C D_{5}\right)$, in the equatorial Pacific $\left(100^{\circ} \mathrm{W}\right.$ to $150^{\circ} \mathrm{W}$, compared with fluctuations of the width of the carbonate belt at $4.5 \mathrm{~km}$, in degrees latitude, in the same region. From Berger, in press.

The locations of Sites 305 and 310 make them ideal for late Neogene paleoclimatic investigation of the North Pacific because they lie close to the present-day boundary between the subtropical central water mass and the transitional (temperate) water mass. Shifts of this boundary over the sites should be recorded in the Hess and Shatsky rise sections.

Paleooceanographic studies require detailed quantitative faunal analyses which are beyond the scope of this paper. However, some changes may be inferred and related to climatic variations recorded in other areas of the North Pacific from semiquantitative analyses.

The well-known coiling preferences of $N$. pachyderma (Ericson, 1959; Bandy, 1960) have been used repeatedly for paleoclimatic studies. Sinistral coiling forms are dominant in surface sediments beneath waters cooler than $10^{\circ} \mathrm{C}$, whereas dextral forms are dominant in surface sediments beneath water warmer than $15^{\circ} \mathrm{C}$. Coiling changes in fossil populations have been used to delineate major changes of surface temperature in various areas of the circum Pacific as far back as the early late Miocene (Bandy, 1967, 1972a; Bandy and Ingle, 1970; Ingle, 1966, 1967, 1973; Asano et al., 1969; Jenkins, 1967b; Kennett, 1970; Kennett et al., 1971; Keany and Kennett, 1972).

A number of cold and warm cycles are recorded in Pleistocene sections from the North Pacific, as shown by various studies of ice-rafted detritus, faunal analyses, and paleomagnetic stratigraphy (Kent et al., 1971; Hays et al., 1969; Olsson, 1971, 1974; Herman, 1970; Ingle, 1973). These studies show that stable climatic conditions prevailed during preglacial early Pleistocene in the Matuyama interval. The cooling, beginning about 1.2 m.y. ago, became very intense between the Jaramillo event and the Brunhes/Matuyama boundary (about 0.8 
m.y. ago). Numerous warm and cold cycles occur in the late Pleistocene interval equivalent to the Brunhes.

A series of oscillations during the Plio-late Miocene interval is recorded along the margin of the northwestern Pacific (Bandy, 1967, 1972a; Ingle, 1967, 1972, 1973a, 1973b; Bandy and Ingle, 1970). In contrast to the warmer early Pleistocene and early Pliocene, the late Pliocene is represented by a cooler interval. During a pronounced subtropical interval in the early Pliocene, which encompasses the $\mathrm{N} .19$ foraminiferal zone at DSDP Site 173, the subtropical zone in the eastern Pacific extended perhaps as far north as latitude $40^{\circ} \mathrm{N}$. An abrupt decrease in surface temperature, bringing subarctic temperatures to the latitude of DSDP Site 173, spans the N.18 foraminiferal zone; the N.18/N.17 boundary (Plio-Miocene boundary) at Site 173 is in the lower portion of this cool interval. An abrupt temperature increase occurs in the latest Miocene again which brings a subtropical facies to $40^{\circ} \mathrm{N}$ latitude. This brief subtropical event is preceded by a lengthy late Miocene interval with subarctic conditions prevailing at Site 173 , during which the $10^{\circ}$ isotherm penetrated south to $28^{\circ} \mathrm{N}$ latitude as reported from Mohole cores (Parker, 1964; Bandy and Ingle, 1970) and surface land sections (Ingle, 1967). This general pattern of temperature fluctuations is duplicated in Japan (Asano et al., 1969).

These late Miocene to Pleistocene climatic cycles which caused the periodical latitudinal migrations of surface isotherms (Figure 8) appear to correlate with variations in carbonate content in cores from the equatorial Pacific. The cooler intervals are associated with higher carbonate content (Arrhenius, 1952; Hays et al., 1969; Saito et al., in press; Kaneps, 1973).

Some faunal changes clearly reflect temperature variations in Shatsky and Hess rise sections although temperature effects cannot always be distinguished from dissolution effects. The major portion of the Hess Rise section yielded exclusively dextral populations of $\mathrm{NeO}$ globoquadrina pachyderma. However, sinistral populations of this species occur in some intervals, which reflect a southward shift of surface isotherms. An intrusion of subarctic waters over Hess Rise is suggested by the occurrence of polar morphotypes (Plate 5, Figures 7, 8 ) of sinistrally coiled $N$. pachyderma at 1.8 meters in the section. This event appears to be younger than 50,000 years (Figure 5) and probably correlates with the peak of the last glacial (Figure 8). The appearance of mixed dextral-sinistral populations of $N$. pachyderma between 14 and 17 meters (Core 3, Sections 1 and 2), dated about 0.7 to 0.8 m.y. on the basis of estimates of sedimentation rates from nannofossil data (Figure 5), marks a time of decreased surface temperatures. This event is probably correlative to the pulse of profound cooling observed in marine sections throughout the northwestern Pacific margin between the Jaramillo event and the Brunhes/Matuyama boundary. Exclusively sinistrally coiled populations of $N$. pachyderma in the interval between Core 7, CC and Core 8, Section 2 (60 to $64 \mathrm{~m}$ ) reflect the major late Miocene cooling recorded in marine sections throughout the North Pacific margins and indicate that the $10^{\circ} \mathrm{C}$ surface isotherm was, at that

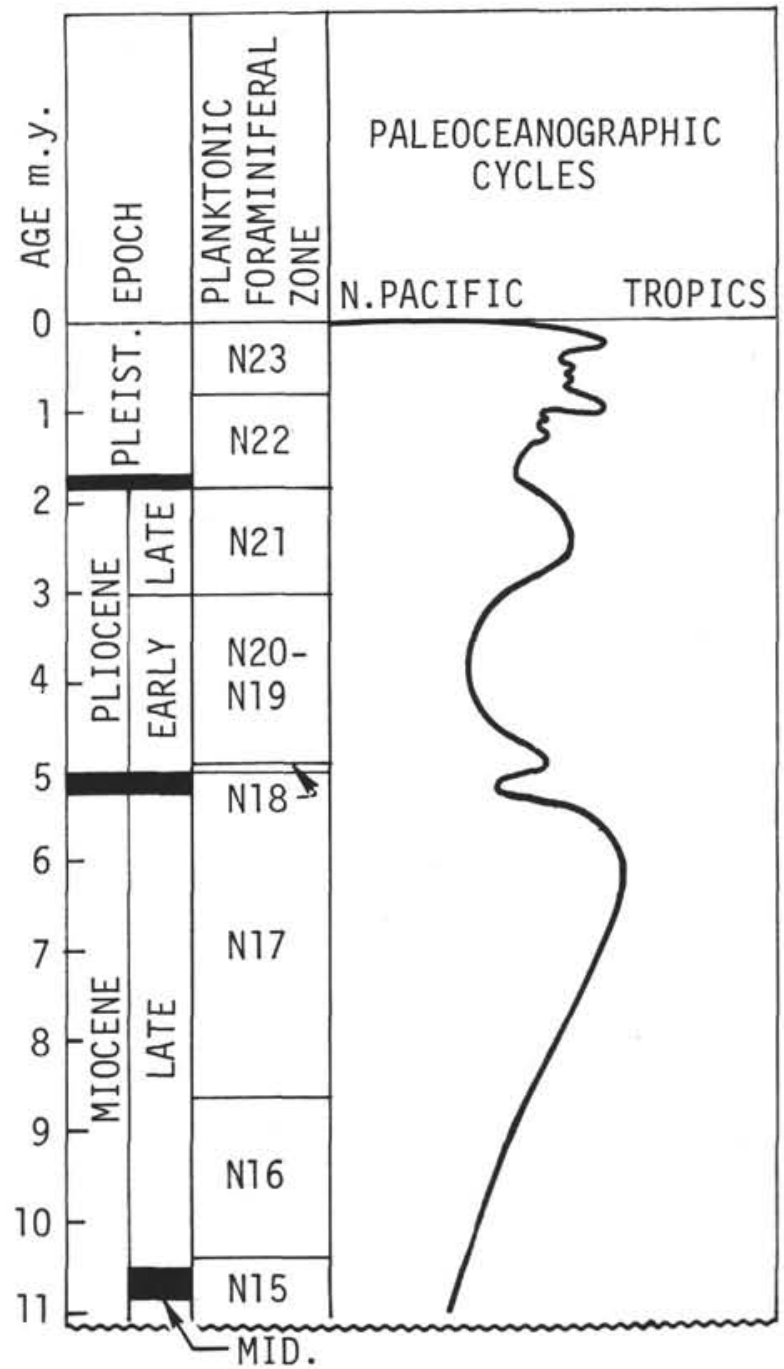

Figure 8. Paleooceanographic cycles, or paleoclimatic cycles in the northeastern Pacific resulting in periodical latitudinal migrations of surface isotherms. Modified from Bandy (1972a) according to data from Ingle $(1973 a, b)$ and the time scale of Berggren (1973) and Berggren and Van Couvering (1974).

time south of Hess Rise. This cooling is observed on Shatsky Rise as well, where contemporaneous $N$. pachyderma faunas contain both sinistrally and dextrally coiled populations. The northward migration of surface isotherms, associated with the end of this period of refrigeration, took place about $5.3 \mathrm{~m} . \mathrm{y}$. ago, based on accumulation rates (Figure 5).

Climatic events prior to about 5.8 m.y. cannot be inferred from Shatsky and Hess rise records because of the absence of $N$. pachyderma, probably due to increased dissolution, which eliminates a valuable paleoclimatic tool, and because the condensed sections prevent detailed investigation.

The occurrence of the warm-water Neogloboquadrina humerosa- $N$. dutertrei group, restricted in this material to the late Pliocene interval, is not easy to explain. These forms, which make a significant contribution to the 
fauna in latest Pliocene, disappear abruptly at the PlioPleistocene boundary just when an increase in temperature is recorded in North Pacific sections. In contrast to Site 310 , the occurrence of the $N$. humerosa- $N$. dutertrei complex is restricted at DSDP Site 173 to the warmer lower Pliocene interval (Ingle, 1973a). However, no interpretation is attempted because of the ambiguity in the relationship between $N$. pachyderma and marginal morphotypes of the $N$. humerosa- $N$. dutertrei group. It is possible that the populations referred to as $N$. humerosa$N$. dutertrei at Site 173 (dominated by five-chambered forms; Ingle, personal communication) and in this material (dominantly four-chambered forms) belong to two different groups with distinct water-mass relationships.

\section{CONCLUSIONS}

Shatsky and Hess rises provide the only available Neogene carbonate sections of the central North Pacific. Despite pronounced calcium carbonate dissolution, foraminiferal faunas proved to be very valuable for biostratigraphic and paleooceanographic interpretations. The location of Sites 305 and 310 in an area intermediate between subtropical and temperate regions and between the CCD and the foraminiferal lysocline make them ideal to study variations in the position of these two levels as well as shifting of water masses through time. Further detailed quantitative study of faunal composition in relation to coiling direction of Neogloboquadrina pachyderma, to morphologic change of Globorotalia crassaformis and to calcium carbonate content will doubtless provide clues for reconstruction of North Pacific circulation during late Neogene time. The expanded Pleistocene section of Hess Rise is especially valuable for paleooceanographic investigation. The recognition in this section of paleooceanographic events reported in other North Pacific sections may enhance biostratigraphic resolution.

Ecologically induced appearances and disappearances of species, as found in this study, show how greatly biostratigraphic interpretations may be biased and how uncertain correlations between temperate and tropical areas can be. The "Mio-Pliocene" boundary, as used by workers of various areas, refers to biostratigraphic events which are significantly different in space and time. This difference leads to discrepancies in worldwide correlations. It is essential, however, to try to obtain precise correlations over large areas in order to estimate the synchroneity of paleooceanographic events and make global paleooceanographic reconstructions. An important biostratigraphic problem which needs to be resolved is the ambiguity in the stratigraphic range of Globorotalia conomiozea. This species defines the Kapitean Stage of New Zeala is reported in late Miocene sections from various areas.

A significant cooling recorded in the late Miocene sections of Shatsky and Hess rises is contemporaneous with the cooling reflected in circum North Pacific sections. However, as long as conflicting correlations between New Zealand and Italian stratigraphies exist, the question remains whether or not the late Miocene cooling noted throughout the North Pacific is synchronous with the substantial cooling in the South Pacific, associated with the Kapitean Stage. This cooling is attributed to glacio-eustatic lowering of sea level caused by an increase of Antarctic ice volume (Kennett, 1968b; Shackleton and Kennett, 1975) and thought to be linked with the initiation of Messinian evaporite deposition in the Mediterranean basin (Berggren and Ul Haq, in press).

\section{ACKNOWLEDGMENTS}

Thanks are due to Helen P. Foreman (Oberlin College) and David Bukry (U.S. Geological Survey) who provided the radiolarian and calcareous nannoplankton data used in this study. The author has benefited in the preparation of this report from valuable discussions with William A. Berggren (Woods Hole Oceanographic Institution), Frances L. Parker (Scripps Institution of Oceanography), James C. Ingle, Jr. (Stanford University), and Richard Z. Poore (U.S. Geological Survey). Frances L. Parker and Wolfgang H. Berger (Scripps Institution of Oceanography) critically reviewed the manuscript.

This study was supported under Oceanographic Section National Science Foundation NSF Grants GA-34145 and DES75-04335.

\section{REFERENCES}

Arrhenius, G., 1952. Sediment cores from the East Pacific: Sweden Deep-Sea Exped. Rept., v. 5, pt. 1.

Asano, K., Ingle, J. C., Jr., and Takayanagi, Y., 1969. Neogene planktonic foraminiferal sequence in northeastern Japan. Intern. Plankt. Conf. 1st, v. 1, p. 14.

Bandy, O. L., 1960. The geologic significance of coiling ratios in the foraminifer Globigerina pachyderma (Ehrenberg): J. Paleontol., v. 34, p. 671.

1967. Foraminiferal definition of the boundaries of the Pleistocene in southern California. In Sears, M. (Ed.), Progress in oceanography, v. 4: New York (Pergamon Press), p. 27.

1972a. Neogene planktonic foraminiferal zones, California and some geologic implications: Palaeography, Palaeoclimatology, Palaeoecology, v. 12, p. 131.

1972b. Origin and development of Globorotalia (Turborotalia) pachyderma (Ehrenberg): Micropaleontology, v. 18, p. 294.

, in press. Messinian evaporite deposition and the Miocene/Pliocene boundary, Pasquasia-Capodarso sections, Sicily. In Saito, T. and Burckle, L. (Eds.), Late Neogene epoch boundaries: Micropaleontology Press, Am. Mus. Nat. History.

Bandy, O. L. and Ingle, J. C., Jr., 1970. Neogene planktonic events and radiometric scale, California. In Bandy, O. L. (Ed.), Radiometric dating and paleontologic zonation: Geol. Soc. Am. Spec. Paper 124, p. 131.

Bandy, O. L., Butler, E. A., and Wright, R. C., 1969. Alaskan Upper Miocene marine glacial deposits and the Turborotalia pachyderma datum plane: Science, v. 166, p. 607.

Bandy, O. L., Casey, R. E., and Theyer, F., 1972. Planktonic events, upper Gilbert-Gauss magnetic epochs: Geol. Soc. Am., Abstracts with programs, v. 4, p. 442.

Bandy, O. L., Frerichs, W. E., and Vincent, E., 1967. Origin, development and geologic significance of Neogloboquadrina Bandy, Frerichs, and Vincent, gen. nov. Cushman Found. Foram. Res., Contrib., v. 18, p. 152.

Banner, F. T. and Blow, W. H., 1965. Progress in the planktonic foraminiferal biostratigraphy of the Neogene: Nature, v. 208, p. 1164.

Berger, W. H., 1968. Planktonic foraminifera: selective solution and paleoclimatic interpretation: Deep-Sea Res., v. 15, p. 31. 
1970. Planktonic foraminifera: selective solution and the lysocline: Marine Geol., v. 8, p. 111.

1971. Sedimentation of planktonic foraminifera: Marine Geol., v. 11, p. 325.

in press. Sedimentation of deep-sea carbonate: maps and models of variations and fluctuations. In Riedel, W. R., and Saito., T. (Eds.), Marine plankton and sediments: Micropaleontology Press, Am. Mus. Nat. History.

Berger, W. H. and von Rad, U., 1972. Cretaceous and Cenozoic sediments from the Atlantic Ocean floor. In Hayes, D. E., Pimm, A. C., et al., Initial Reports of the Deep Sea Drilling Project, Volume 14: Washington (U.S. Government Printing Office), p. 787.

Berger, W. H. and Winterer, E. L., 1974. Plate stratigraphy and the fluctuating carbonate line. In Hsü, K. J. and Jenkyns, H. C. (Eds.), Pelagic sediments on land and under the sea: Spec. Publ. Internatl. Assoc. Sedimentol., v. 1, p. 59.

Berggren, W. A., 1972a. Cenozoic biostratigraphy and paleobiogeography of the North Atlantic. In Laughton, S. L., Berggren, W. A., et al., Initial reports of the Deep Sea Drilling Project, Volume 12: Washington (U.S. Government Printing Office), p. 965.

1972b. A Cenozoic time-scale-some implications for regional geology and paleobiogeography: Lethaia, v. 5, p. 195.

1973. The Pliocene time scale: calibration of planktonic foraminiferal and calcareous narinoplankton zones: Nature, v. 243, p. 391.

Berggren, W. A. and Amdurer, M., 1973. Late Paleogene (Oligocene) and Neogene planktonic foraminiferal biostratigraphy of the Atlantic Ocean (lat $30^{\circ} \mathrm{N}$ to lat $30^{\circ} \mathrm{S}$ ): Riv. Ital. Paleontol., v. 79, p. 337.

Berggren, W. A. and Ul Haq, B., in press. Biochronology, Paleoecology and calcareous plankton biostratigraphy of the Andalusian Stage (Late Miocene).

Berggren, W. A. and Van Couvering, J. A., 1974. The late Neogene: Biostratigraphy, biochronology and paleoclimatology of the last 15 million years in marine and continental sediments: Paleogeogr., Paleoecol., Paleoclimatol., v. 16, p. 1.

Berggren, W. A., Phillips, J. D., Bertels, A., and Wall, D., 1967. Late Pliocene-Pleistocene stratigraphy in deep-sea cores from the south-central North Atlantic: Nature, v. 216 , p. 253.

Boellstorff, J. and Steineck, P. L., 1974. Fission-track absolute age of Plio-Pleistocene volcanic ashes: Geol. Soc. Am., Abstracts with programs, v. 6, p. 660 .

Bolli, H. M., 1957. Planktonic foraminifera from the Oligocene-Miocene Cipero and Lengua formations of Trinidad, B. W. I.: U.S. Nat. Museum Bull. 215, p. 97.

1966. Zonation of Cretaceous to Pliocene marine sediments based on planktonic foraminifers: Bol. Inform., Asoc. Venez. Geol., Min., Petrol., v. 9, p. 3.

1970. The foraminifera of Sites 23-31. In Bader, R. G., Gerard, R. D., et al., Initial Reports of the Deep Sea Drilling Project, Volume 4: Washington (U.S. Government Printing Office), p. 577.

Blow, W. H., 1969. Late middle Eocene to Recent planktonic foraminifera biostratigraphy: Int. Conf. Plankt. Microfossils, 1st Proc., Brönnimann, P. and Renz, H. H. (Eds.), Leiden (Brill), v. 1, p. 199.

Bradshaw, J. S., 1959. Ecology of living planktonic foraminifera in the north and equatorial Pacific Ocean: Cushman Found. Foram. Res. Contrib., v. 10, p. 25.

Bukry, D., 1973. Low-latitude coccolith biostratigraphy zonation. In Edgar, N. T., Saunders, J. B., et al., Initial Reports of the Deep Sea Drilling Project, Volume 15: Washington (U.S. Government Printing Office), p. 685.
Catalano, R. and Sprovieri, R., 1971. Biostratigrafia di alcune serie Saheliane (Messiniano Inferiore) in Sicilia. In Farinacci, A., (Ed.), Planktonic Conf. Proc. 2nd, Rome, 1970: Rome, (Tecnoscienza), p. 211.

Casey, R. E., 1972. Neogene radiolarian biostratigraphy and paleotemperatures: southern California, the Experimental Mohole, Antarctic Core E14-8. Paleogeogr., Paleoclimatol., Paleoecol., v. 12, p. 115.

in press. Late Neogene radiolarian biostratigraphy related to magnetostratigraphy, Polar to Tropics: O. L. Bandy Memorial Volume.

Casey, R. E., Price, A. B., and Swift, C. A., 1972. Radiolarian definition and paleoecology of the late Miocene to early Pliocene in southern California. In Stinemeyer, E. H. (Ed.), The Pacific Coast Miocene biostratigraphic symposium, March 9-10, 1972, Bakersfield, California. Pac. Section, Soc, Econ. Paleo. Mineral., p. 226.

Collen, J. D. and Vella, P., 1973. Pliocene planktonic foraminifera, southern North Island, New Zealand: J. Foram. Res., v. 3, p. 13.

Cox, A., 1969. Geomagnetic reversals: Science, v. 163, p. 237.

Ericson, D. B., 1959. Coiling direction of Globigerina pachyderma as a climatic index: Science, v. 130, p. 219.

Ericson, D. B., Ewing, M., and Wollin, G., 1963. PliocenePleistocene boundary in deep-sea sediments: Science, v. 139, p. 727.

Fischer, A. G., Heezen, B. C., Boyce, R. E., Bukry, D., Douglas, R. G., Garrison, R. E., Kling, S. A., Krasheninnikov, Lisitzin, A. P. and Pimm, A. C., 1971. Initial Reports of the Deep Sea Drilling Project, Volume 6: Washington (U.S. Government Printing Office).

Fleisher, R. L., 1974. Cenozoic planktonic foraminifera and biostratigraphy. Arabian Sea, Deep Sea Drilling Project, Leg 23A. In Whitmarsh, R. B., Weser, O. E., Ross, D. A., et al., Initial Reports of the Deep Sea Drilling Project, Volume 23: Washington (U.S. Government Printing Office), p. 1001 .

Gartner, S., 1973. Absolute chronology of the late Neogene calcareous nannofossil succession in the Equatorial Pacific: Geol. Soc. Am. Bull., v. 84, p. 2021.

Glass, B., Ericson, D. B., Heezen, B. C., Opdyke, N. D., and Glass, J. A., 1967. Geomagnetic reversals and Pleistocene chronology: Nature, v. 216, p. 437.

Hays, J. D., 1970. Stratigraphy and evolutionary trends of Radiolaria in North Pacific deep-sea sediments: Geol. Soc. Am., Mem. 126, p. 185.

Hays, J. D. and Berggren, W. H., 1971. Quaternary Boundaries. In Funnel, B. M. and Riedel, W. R. (Eds.), Micropalaeontology of oceans: Cambridge (Cambridge Univ. Press), p. 669.

Hays, J. D., Saito, T., Opdyke, N. D., and Burckle, L. H., 1969. Pliocene-Pleistocene sediments of the equatorial Pacific: their paleomagnetic, biostratigraphic, and climatic record: Am. Bull. Geol. Soc., v. 80, p. 1481.

Herman, Y., 1970. Arctic paleo-oceanography in late Cenozoic time: Science, v. 169, p. 474.

Hornibrook, N. de B., 1958. New Zealand Upper Cretaceous and Tertiary foraminiferal zones and some overseas correlations: Micropaleontology Press, Am. Mus. Nat. History, v. 4, p. 25-38.

Hornibrook, N. de B. and Edwards, A. R., 1971. Integrated planktonic foraminiferal and calcareous nannoplankton datum levels in the New Zealand Cenozoic. In Farinacci, A., (Ed.), Plankt. Conf. Proc. 2nd, Rome, 1970: Rome (Tecnoscienza), p. 649.

Ikebe, N., Takayanagi, Y., Chiji, M., and Chinzei, K., 1972. Neogene biostratigraphy and radiometric time scale of Japan-an attempt at international correlation: Pacific Geol., v. 4, p. 39. 
Ingle, J. C., Jr., 1967. Foraminiferal biofacies and the Miocene-Pliocene boundary in southern California: Am. Paleontol. Bull., v. 52, p. 217.

1972. Biostratigraphy and paleoecology of early Miocene through early Pleistocene benthonic and planktonic foraminifera, San Joaquin Hills-Newport Bay, Orange County, California. In Stinemeyer, E. H. (Ed.), The Pacific Coast Miocene biostratigraphic Symp., March 9-10, 1972. Bakersfield, California. Pacific Sect., Soc. Econ. Paleontol. Mineral, p. 255.

1973a. Neogene foraminifera from the northeastern Pacific Ocean, Leg 18, Deep Sea Drilling Project. In Kulm, L. D., von Huene, R., et al., Initial Reports of the Deep Sea Drilling Project, Volume 18: Washington (U.S. Government Printing Office), p. 517.

1973b. Summary comments on Neogene biostratigraphy, physical stratigraphy, and paleo-oceanography in the marginal northeastern Pacific Ocean. In Kulm, L. D., von Huene, R., et al., Initial Reports of the Deep Sea Drilling Project, Volume 18: Washington (U.S. Government Printing Office), p. 949.

Jenkins, D. G., 1966. Planktonic foraminiferal zones and new taxa from the Danian to lower Miocene of New Zealand: New Zealand J. Geol. Geophys., v. 8, p. 1088.

1967a. Planktonic foraminiferal zones and new taxa from the lower Miocene to the Pleistocene of New Zealand: New Zealand J. Geol. Geophys., v. 10, p. 1064.

1967b. Recent distribution, origin and coiling ratio changes in Globorotalia pachyderma (Ehrenberg): Micropaleontology, v. 13, p. 195-203.

1971. New Zealand Cenozoic Planktonic Foraminifera: New Zealand Geol. Surv. Paleont. Bull., v. 42, 278 p.

Jenkins, D. G. and Orr, W. N., 1972. Planktonic foraminiferal biostratigraphy of the eastern equatorial Pacific DSDP Leg 9. In Worzel, J. L., Bryant, W., et al., Initial Reports of the Deep Sea Drilling Project, Volume 9: Washington (U.S. Government Printing Office), p. 1059.

Kaneps, A., 1973. Carbonate chronology for Pliocene deepsea sediments. In van Andel, Tj. H., Heath, G. R., et al., Initial Reports of the Deep Sea Drilling Project, Volume 16: Washington (U.S. Government Printing Office), p. 873.

Keany, J. and Kennett, J. P., 1972. Pliocene-early Pleistocene paleoclimatic history recorded in Antarctic-Subantarctic deep-sea cores: Deep-Sea Res., v. 19, p. 529.

Kennett, J. P., 1966. The Globorotalia crassaformis bioseries in north Westland and Marlborough, New Zealand: Micropaleontology, v. 12, p. 235.

1967. Recognition and correlation of the Kapitean Stage (upper Miocene, New Zealand): New Zealand J. Geol. Geophys., v. 10, p. 143.

1968a. Latitudinal variation in Globigerina pachyderma (Ehrenberg) in surface sediments of the southwest Pacific Ocean: Micropaleontology, v. 14, p. 305. 1968b. Paleo-oceanographic aspects of the foraminiferal zonation in the upper Miocene-lower Pliocene of New Zealand: Gior. Geol., v. 35, p. 143.

1970. Pleistocene paleoclimates and foraminiferal biostratigraphy in Subantarctic deep-sea cores: Deep-Sea Res., v. 17, p. 125.

1973. Middle and late Cenozoic planktonic foraminiferal biostratigraphy of the southwest Pacific-DSDP Leg 21. In Burns, R. E., Andrews, J. E., et al., Initial Reports of the Deep Sea Drilling Project, Volume 21: Washington (U.S. Government Printing Office), p. 575-640.

Kennett, J. P. and Watkins, N. D., 1972. The biostratigraphic, climatic, and paleomagnetic records of late Mio- cene to early Pleistocene sediments in New Zealand [abs.]: Internat. Geol. Cong., 24th, Montreal 1972, p. 538. 1974. Late Miocene-Early Pliocene paleomagnetic stratigraphy, paleoclimatology, and biostratigraphy in New Zealand: Geol. Soc. Am. Bull., v. 85, p. 1385.

Kennett, J. P., Watkins, N. D., and Vella, P., 1971. Paleomagnetic chronology of Pliocene-early Pleistocene climates and the Plio-Pleistocene boundary in New Zealand: Science, v. 171 , p. 276.

Kent, D., Opdyke, N. D., and Ewing, M., 1971. Climate change in the North Pacific using ice-rafted detritus as a climatic indicator: Geol. Soc. Am. Bull., v. 82, p. 2741.

Kling, S. A., 1973. Radiolaria from the Eastern North Pacific, Deep Sea Drilling Project, Leg 18. In Kulm, L. D., von Huene, R., et al., Initial Reports of the Deep Sea Drilling Project, Volume 18: Washington (U.S. Government Printing Office), p. 617.

Kobayashi, K., Kitazawa, K., Kanaya, T., and Sakai, T., 1971. Magnetic and micropaleontological study of deep-sea sediments from the west-central equatorial Pacific: DeepSea Res., v. 18, p. 1045.

Krasheninnikov, V. A., 1971. Stratigraphy and foraminifera Cenozoic pelagic sediments of the Pacific northwestern part (based on materials of deep sea drilling): Voprosy Mikropal., 14, Akad. Nauk. Trud. Krash. Zham., p. 140 (in Russian).

Lidz, B., 1972. Globorotalia crassaformis morphotype variations in Atlantic and Caribbean deep-sea cores: Micropaleontology, v. 18 , p. 194.

Martini, E., 1971. Standard Tertiary and Quaternary calcareous nannoplankton zonation. In Farinacci, A. (Ed.), Plankt. Conf., Proc. 2nd, Rome, 1970: Rome (Tecnoscienza), p. 739.

Olsson, R. K., 1971. Pliocene-Pleistocene planktonic foraminiferal biostratigraphy of the northeastern Pacific: In Farinacci, A. (Ed.), Plankt. Conf. Proc., 2nd, Rome, 1970: Rome (Tecnoscienza), p. 921-928.

1974. Pleistocene paleooceanography and Globigerina pachyderma (Ehrenberg): J. Foram. Res., v. 4, p. 47.

Parker, F. L., 1964. Foraminifera from the experimental MOHOLE drilling near Guadalupe Island, Mexico: J. Paleontol., v. 38 , p. 617.

1967. Late Tertiary biostratigraphy (planktonic foraminifera) of tropical Indo-Pacific deep-sea cores: Am. Paleontol. Bull., v. 52.

1973. Late Cenozoic biostratigraphy (planktonic foraminifera) of tropical Atlantic deep-sea sections: Rev. Españ. Micropaleontol., v. 5, p. 253.

Parker, F.L. and Berger, W. H., 1971. Faunal and solution patterns of planktonic foraminifera in surface sediments of the South Pacific: Deep-Sea Res., v. 18, p. 73.

Poore, R. Z. and Berggren, W. A., 1974. Pliocene biostratigraphy of the Labrador Sea: Calcareous Plankton: J. Foram. Res., v. 4, p. 91.

, in press. Late Cenozoic planktonic foraminiferal biostratigraphy and paleoclimatology of the northeastern Atlantic: DSDP Site 116: J. Foram. Res.

Riedel, W. R. and Sanfilippo, A., 1971. Cenozoic Radiolaria from the western tropical Pacific, Leg 7. In Winterer, E. L., Riedel, W. R., et al., Initial Reports of the Deep Sea Drilling Project, Volume 7: Washington (U.S. Government Printing Office), p. 1529-1672.

Saito, T., 1963. Miocene planktonic foraminifera from Honshu, Japan: Sci. Rept. Tohoku Univ., Sec. Series (Geol.), v. 35, p. 123.

Saito, T., Burckle, L., and Hays, J. D., in press. Micropaleontologic and paleomagnetic data on the Miocene/Pliocene 
boundary. In Saito, T. and Burckle, L. (Eds.), Late Neogene epoch boundaries: Micropaleontology Press, Am. Mus. Nat. History.

Shackleton, N. J. and Kennett, J. P., 1975. Late Cenozoic oxygen and carbon isotopic changes at DSDP Site 284: Implications for glacial history of the Northern Hemisphere and Antarctica. In Kennett, J. P., Houtz, R. E. et al., Initial Reports of the Deep Sea Drilling Project, Volume 29: Washington (U.S. Government Printing Office), p. 743.

Theyer, F., 1973. Globorotalia truncatulinoides datum plane: evidence for a Gauss (Pliocene) age in subantarctic cores: Nature Phys. Sci., v. 241, p. 142.
Theyer, F. and Hammond, S. R., 1974. Paleomagnetic polarity sequence and radiolarian zones, Brunhes to Polarity epoch 20: Earth Planet. Sci. Lett., v. 22, p. 307.

Tully, J.P., 1965. Oceanographic regions and processes in the seasonal zone of the North Pacific Ocean. In Yoshida, K. (Ed.), Studies in Oceanography (Hidaka memorial volume): Seattle (Univ. Washington Press) p. 68.

van Andel, Tj. H., and Moore, T. C., 1974. Cenozoic calcium carbonate distribution and calcite compensation depth in the central equatorial Pacific: Geology, v. 2, p. 87.

Van Couvering, J. A. and Berggren, W. A., in press. The biostratigraphical basis of the Neogene time-scale. In Hazel, J. E. and Kauffman, E. (Eds.), New concepts in Biostratigraphy: Pal. Soc. Am. Spec. Publ. 


\section{PLATE 1}

Figures 1-5 Globorotalia limbata (d'Orbigny).

1,2 . Sample $305-5-5,122-125 \mathrm{~cm}$.

1: Umbilical view, $\times 47$.

2: Side view, $\times 50$.

3. Sample 310-5-1, 20-22 cm, spiral view, $\times 62$.

4,5. Sample 305-5, CC.

4: Umbilical view $\times 80$.

5: Side view, $\times 80$.

Figures 6-10 Globorotalia tumida (Brady).

6,7. Sample $310-7-3,20-22 \mathrm{~cm}$.

6: Umbilical view, $\times 65$.

7: Side view, $\times 52$.

8-10. Sample 305-5-3, $122-125 \mathrm{~cm}$.

8: Umbilical view, $\times 48$.

9: Side view, $\times 49$.

10: Spiral view, $\times 48$.

Figures 11, 12 Form intermediate between Globorotalia plesiotumida Blow and Banner and Globorotalia tumida (Brady). Sample 305-6-1, 129-131 cm, $\times 48$.

11: Umbilical view.

12: Side view.

Figures 13-19 Globorotalia inflata (d'Orbigny)

13-15. Sample 310-3-6, 123-125 cm, $\times 71$.

13: Umbilical view.

14: Side view.

15: Spiral view.

16. Sample $310-4-2,126-128 \mathrm{~cm}$, umbilical view, $\times 71$.

17-18. Sample 310-5-4, 33-35 cm, $\times 71$.

17: Umbilical view.

18: Side view.

19: Spiral view. 

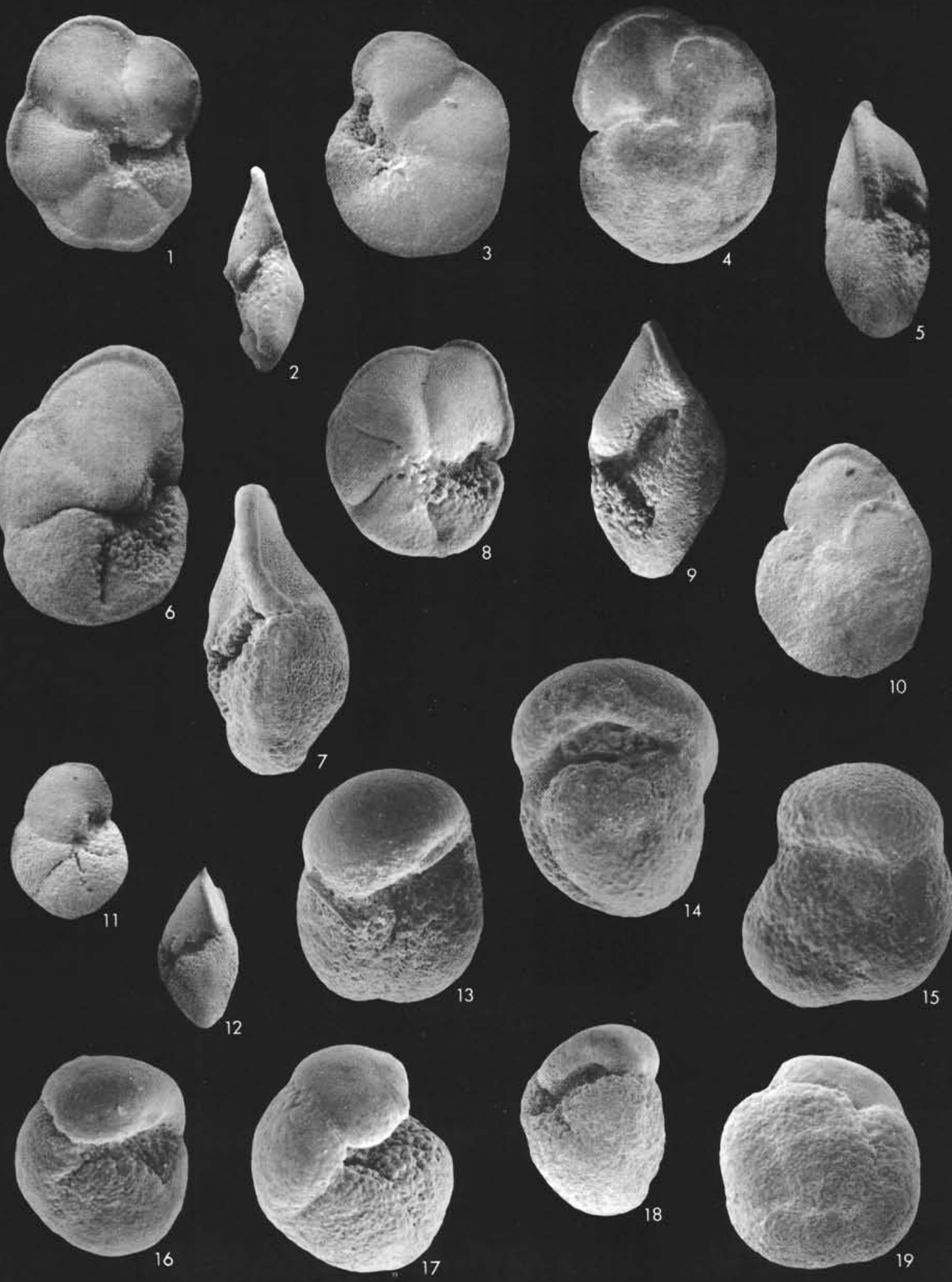


\section{PLATE 2}

Figures 1, 2 Globorotalia inflata (d'Orbigny).

1. Sample 310-5-5, 122-124 cm, umbilical view, $\times 71$.

2. Sample 310-5-6, 22-24 cm, umbilical view, $\times 71$.

Figures 3, 4 Form intermediate between Globorotalia puncticulata (Deshayes) and Globorotalia inflata (d'Orbigny). Sample 305-3-1, 108-110 cm, × 71 .

3. Umbilical view.

4. Side view.

Figures 5-8 Globorotalia puncticulata (Deshayes).

5-7. Sample 310-7-1, 120-122 cm, $\times 71$.

5: Umbilical view.

6: Spiral view.

7: Side view.

8. Sample $310-5, \mathrm{CC}$, umbilical view, $\times 71$.

Figures 9-12 Globorotalia sphericomiozea Walters

9-11. Sample 310-7-1, 120-122 cm, × 71 .

9,10: Umbilical views.

11: Spiral view.

12. Sample 305-4-2, 135-137 cm, side view, $\times 71$.

Figures 13-21 Globorotalia conoidea Walters s.l.

13,14. Sample 310-7-2, 123-125 cm, $\times 71$.

13: Umbilical view.

14: Spiral view.

15-21. Sample 310-7-3, 20-22 cm, $\times 71$.

15-18: Umbilical views.

19,20: Side views.

21: Spiral view.

Figures 22-24 Globorotaliid test fragments resulting from carbonate dissolution.

22. Sample 310-8-3, 123-125 cm, $\times 71$.

23,24 . Sample $305-5, \mathrm{CC}, \times 71$. 


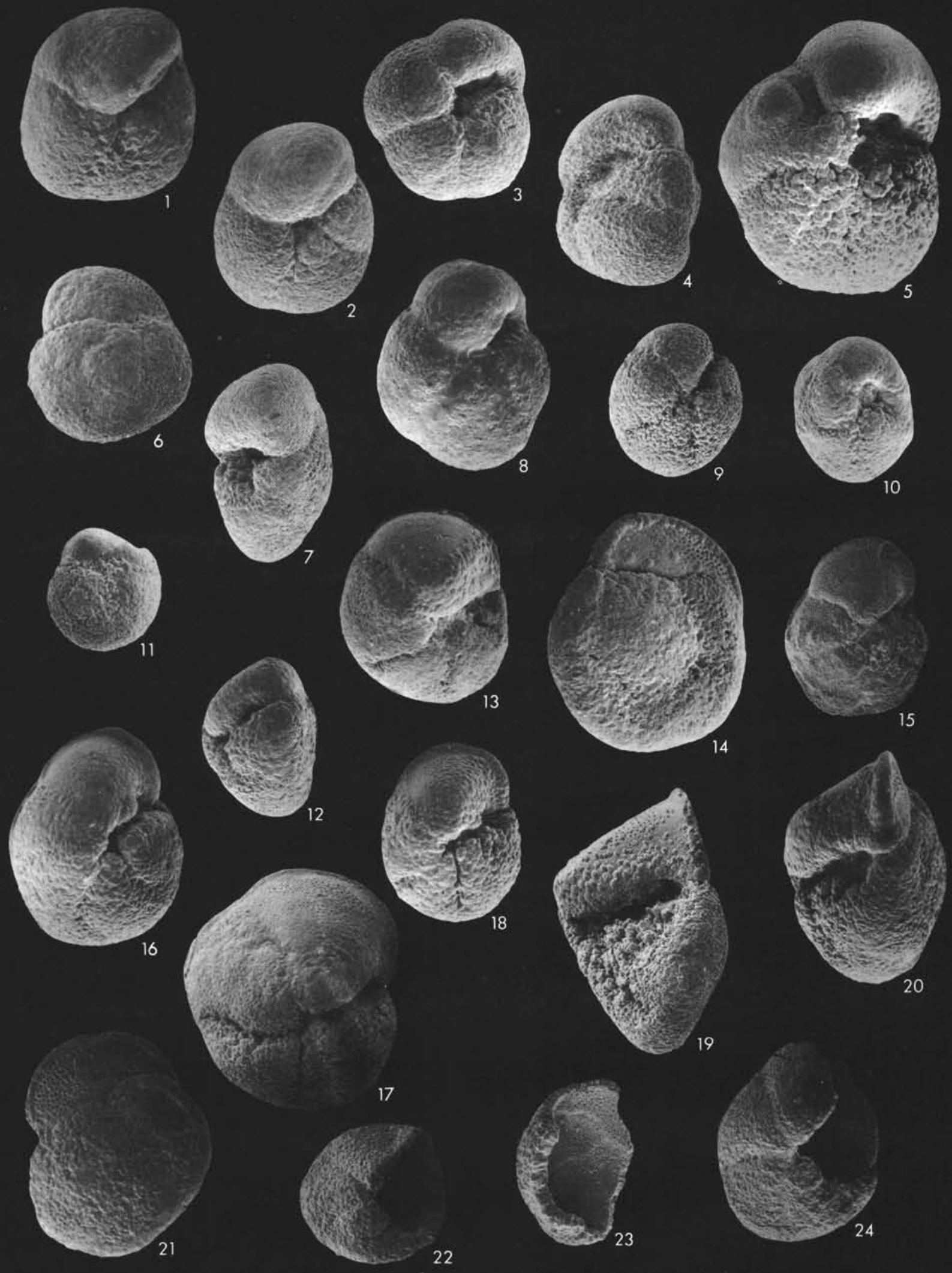




\section{PLATE 3}

Figures 1-14 Globorotalia crassaformis (Galloway and Wissler).

1-3. Sample 313-1-1, 100-102 cm, $\times 71$.

1: Umbilical view.

2: Side view.

3: Spiral view.

4-6. Sample 310-1, CC, $\times 71$.

4: Umbilical view.

5: Side view.

6: Spiral view.

7. Sample 305-2-1, 90-92 cm, umbilical view, $\times 62$.

8,9. Sample $305-5-1,124-127 \mathrm{~cm}, \times 71$.

8: Side view.

9: Spiral view.

10,11. Sample 310-4-5, $54-57 \mathrm{~cm}, \times 71$.

10: Umbilical view.

11: Side view.

12. Sample $305-4-3,122-125 \mathrm{~cm}$, side view, $\times 71$.

13,14. Sample 310-6-4, $122-124 \mathrm{~cm}, \times 71$.

13: Umbilical view.

14: Spiral view.

Figures 15, 16 Globorotalia truncatulinoides (d'Orbigny).

15. Sample $305-1-3,118-120 \mathrm{~cm}$, side view, $\times 75$.

16. Sample $310-3-3,122-124 \mathrm{~cm}$, side view, $\times 71$.

Figures 17-19 Globorotalia tosaensis Takayanagi and Saito.

17. Sample $310-3$, CC, side view, $\times 71$.

18. Sample $305-1-6,70-72 \mathrm{~cm}$, umbilical view, $\times 71$.

19. Sample $305-2-2,125-127 \mathrm{~cm}$.

19a: Spiral view, $\times 71$.

19b: Detail of Figure 19a showing the porous rounded edge, $\times 355$. 

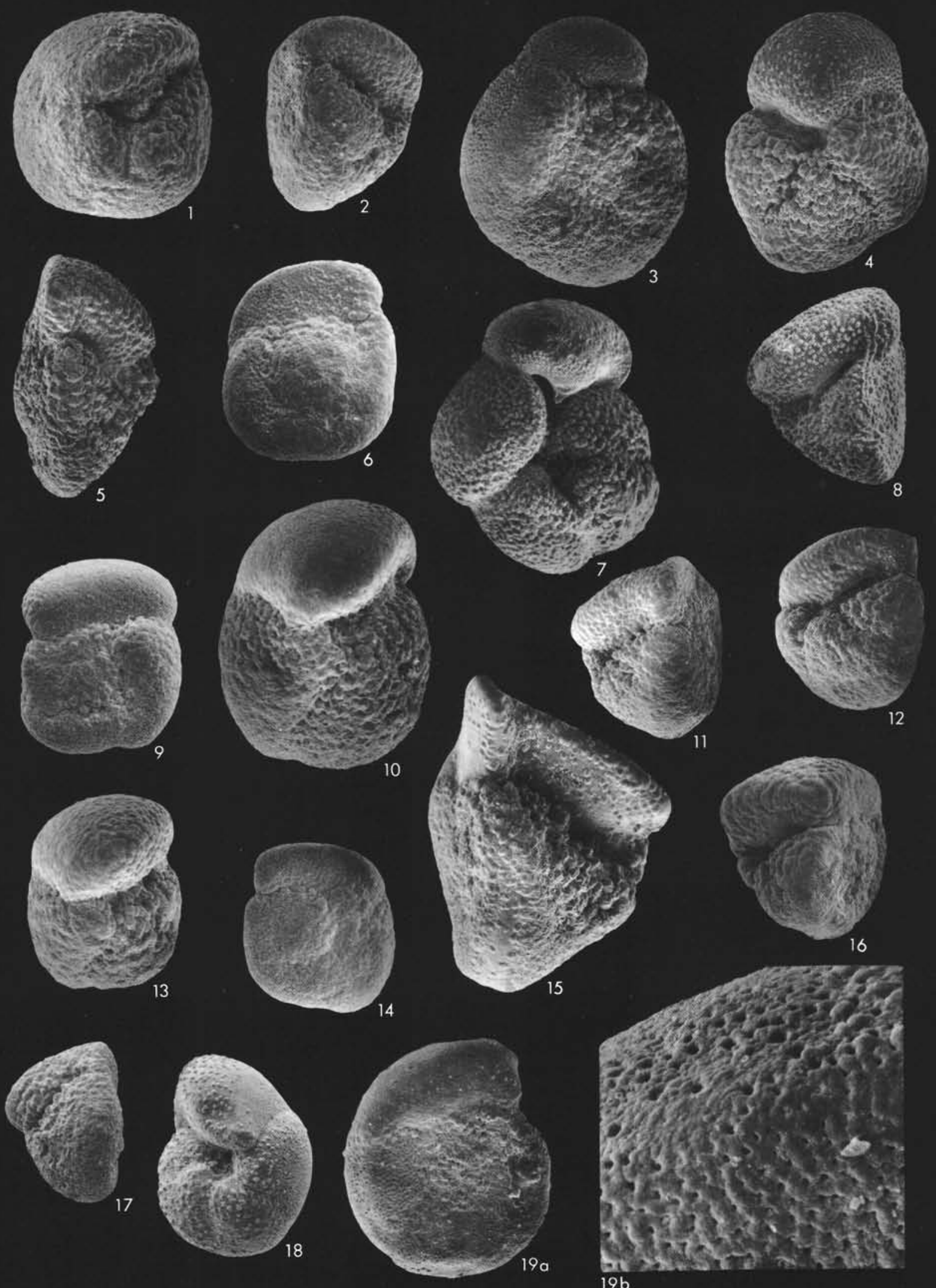


\section{PLATE 4}

Figures 1-3 Globorotalia scitula (Brady). Sample 305-1-3, 118$120 \mathrm{~cm}, \times 71$.

1. Umbilical view.

2. Side view.

3. Spiral view.

Figures 4-6 Globorotalia hirsuta (d'Orbigny). Sample 305-1-2, $100-102 \mathrm{~cm}, \times 71$.

4. Umbilical view.

5. Side view.

6. Spiral view.

Figures 7-10 "Globigerina" nepenthes Todd.

7-9. Sample 310-8-2, 50-52 cm.

7,9: Umbilical views, $\times 142$.

8: Detail of Figure 7 showing the cancellate surface-wall texture, $\times 711$.

10. Sample 310-9-1, $127-129 \mathrm{~cm}$, spiral view showing signs of dissolution, $\times 142$.

Figures 11-16 Neogloboguadrina dutertrei (d'Orbigny).

11-13. Sample 310-4-1, 156-158 cm, $\times 71$.

11,12: Umbilical views.

13: Side view.

14. Sample 310-4-2, $126-128 \mathrm{~cm}$, umbilical view, $\times 71$.

15,16 . Sample $310-4-4,125-127 \mathrm{~cm}$, umbilical views, $\times 71$. 

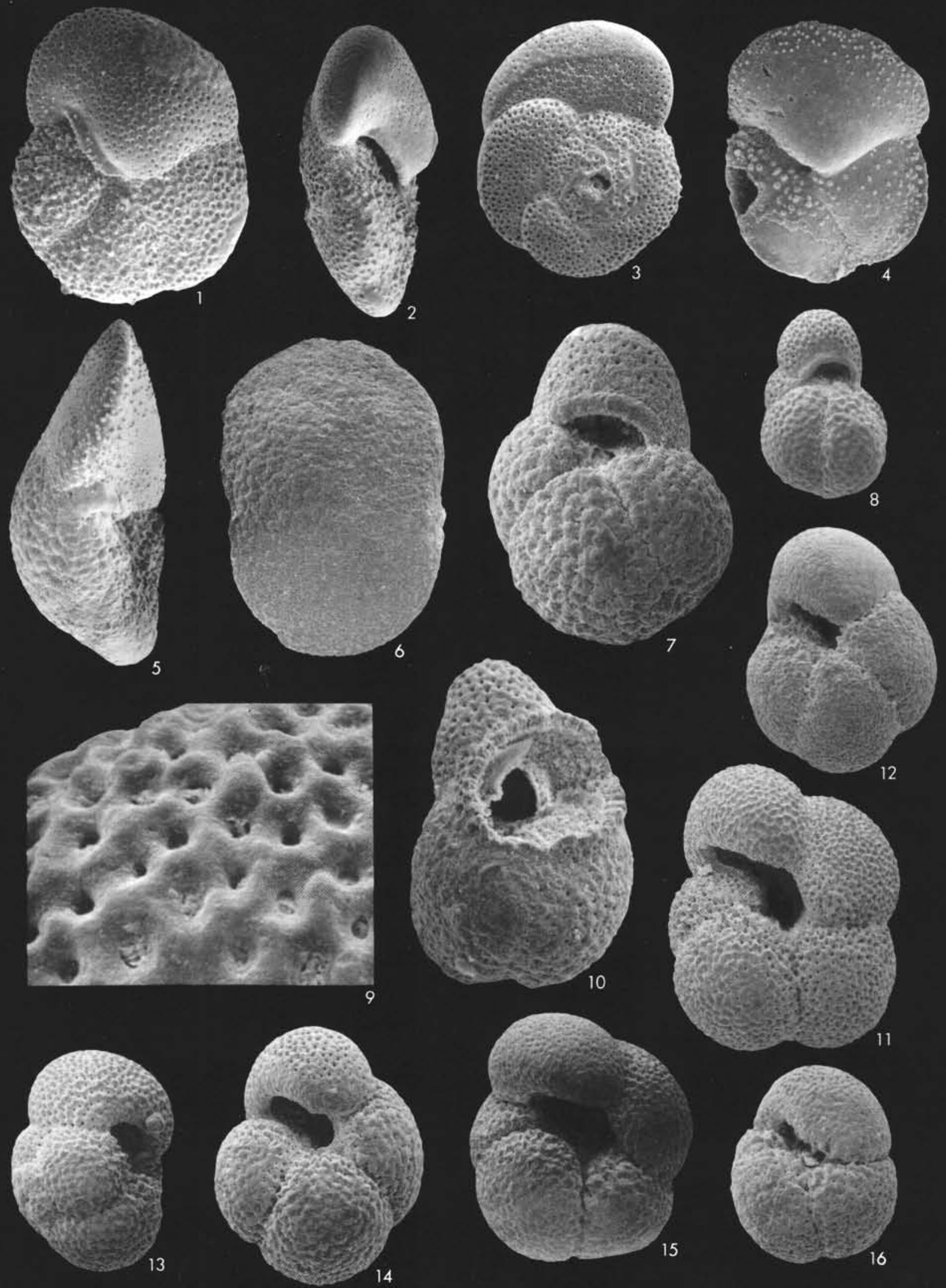


\section{PLATE 5}

Figures 1-3 Neogloboguadrina dutertrei (d'Orbigny). Sample 310-4-5, 54-56 cm, $\times 71$.

1. Umbilical view.

2. Side view.

3. Spiral view.

Figures 4, 5 Form intermediate between Neogloboquadrina humerosa (Takayanagi and Saito) and Neogloboquadrina dutertrei (d'Obigny). Umbilical views, $\times 71$.

4. Sample 310-5-1, 20-22 cm.

5. Sample $310-5-2,124-126 \mathrm{~cm}$.

Figures 6-17 Neogloboquadrina pachyderma (Ehrenberg).

$\times 142$.

6. Sample 305-1-2, 100-102, umbilical view.

7,8. Sample 310-1-2, 33-35 cm, polar morphotypes, umbilical view.

9-11. Sample 310-4-2, 126-128 cm.

9: Umbilical view.

10: Side view.

11: Spiral view.

12-13. Sample 310-7-4, 50-52 cm.

12: Umbilical view.

13: Side view.

14-16 Sample 310-8-1, 50-52 cm.

14,15: Umbilical views.

16: Side view.

17. Sample $310-8-2,50-52 \mathrm{~cm}$, spiral view. 

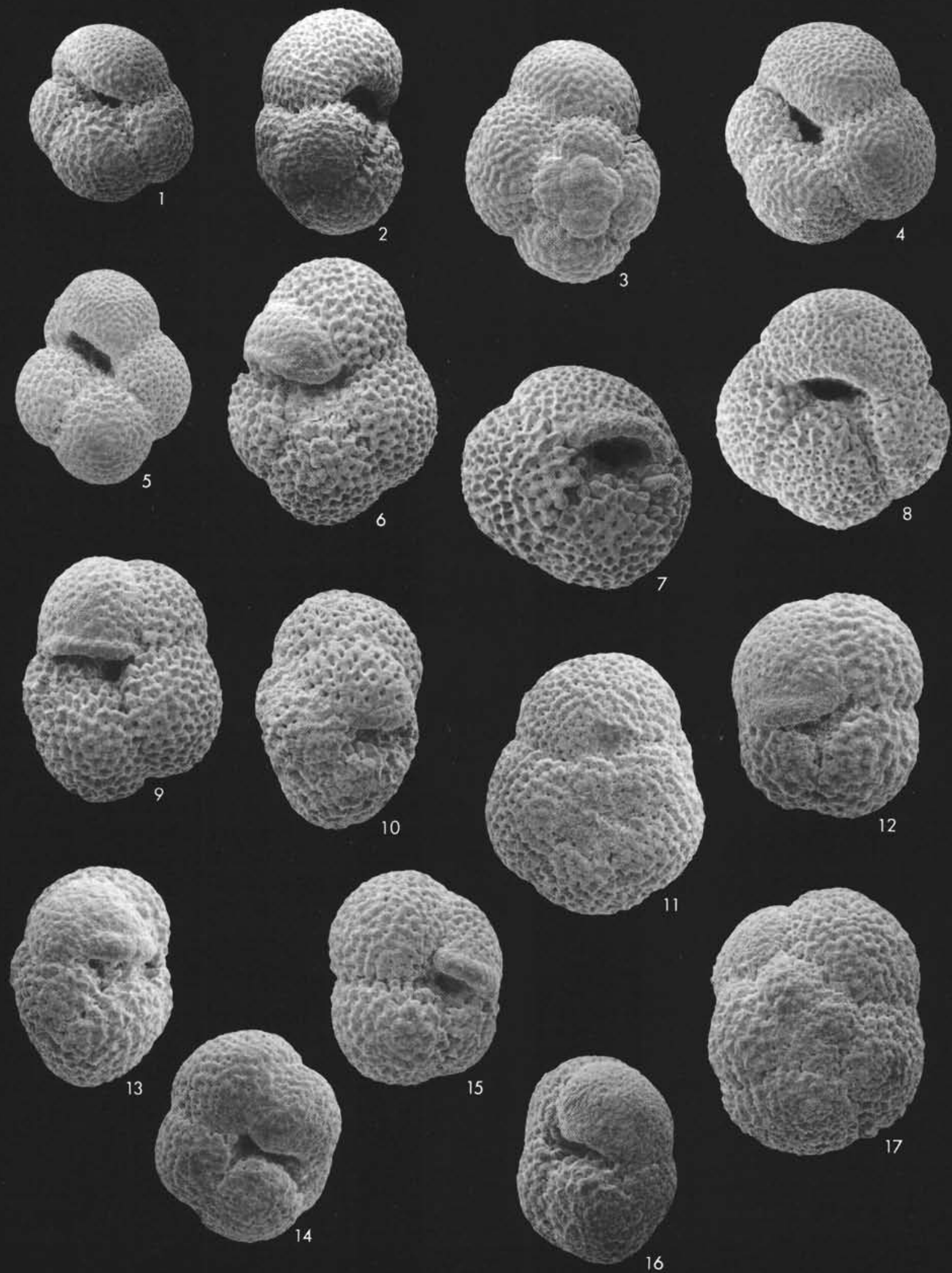